\section{An overview of the second year of a mentoring program designed for special education teachers of children with autism in the early years of profession}

\section{Öğretmenliğin ilk yıllarında otizm spektrum bozukluk tanılı öğrencilerle çalışan özel eğitim öğretmenlerine uygulanan mentorluk programının ikinci yılına bakış}

\author{
Yeşim Güleç Aslan ${ }^{1}$ \\ Canan Sola Özgüç ${ }^{2}$
}

\begin{abstract}
Early years of teaching profession can be hard especially for teachers of children with autism spectrum disorder (ASD) due to difficulties of ASD. Work adjustment programs are designed to facilitate first years of teachers who may have difficulty in adjusting to teaching, performing teaching and coping with behavior problems. These programs can include services aimed to help acquire knowledge and skills, mentoring, and consulting. This paper presents a qualitative case study on the second year of an online mentoring program designed for teachers of students with ASD. The study participants include seven teachers graduated from the Education of Mentally Disabled Program and working in special education implementation centers students with ASD. The data was collected through artifacts, opinion form, and researcher diary. The results show that the online mentoring program involves topics for the participants' needs and offers benefits such as professional development and adjustment. The results also include participants' views on the weaknesses and strengths of the program.
\end{abstract}

Özet

Öğretmenlik mesleğinin ilk yılları, otizm spektrum bozukluğu (OSB) öğrencilerle çalışan öğretmenler için, OSB'nin kendine özgü güçlüklerinden dolayı zor geçebilmektedir. Öğretmenliğe alışmanın yanı sıra, öğretim sunmada ve davranış sorunlariyla baş etmede sorunlar yaşayabilen bu öğretmenlerin mesleklerinin ilk yıllarını başarılı bir şekilde geçirmelerini sağlayan işe uyum programları; bilgi ve beceri kazandırma amaçlı hizmetler, mentorluk, danışmanlık şeklinde yürütülebilmektedir. Bu araştırmada, mesleğinin ilk yıllarını OSB alanında çalışan öğretmenlere yönelik bir çevrimiçi mentorluk programının ikinci yllı nitel vaka çalışmasıyla incelenmiştir. Katılımcilar, özel eğitim uygulama merkezleri ve bağımlı Otistik Çocuklar Eğitim Merkezlerinde (OÇEM) göreve başlayan Z.E.Ö. lisans programı mezunu yedi öğretmendir. Veriler, süreç ürünleri, görüss formu ve araştırmac1 günlükleri ile toplanmıştır. Betimsel analiz sonucundaki bulgular çevrimiçi mentorluk programının katılımcıların ihtiyaçlarına yönelik konulardan oluştuğunu, programin mesleki gelişim, uyum gibi faydaları olduğunu

\footnotetext{
${ }^{1}$ Assoc. Prof. Dr., Istanbul Medeniyet University, Faculty of Educational Science, yesim.gulec@medeniyet.edu.tr ${ }^{2}$ Asst. Prof. Dr., Sakarya University, Faculty of Education, csola@sakarya.edu.tr
} 
Güleç Aslan, Y., \& Sola Özgüç, C. (2017). Öğretmenliğin ilk yıllarında otizm spektrum bozukluk tanılı öğrencilerle çalışan özel eğitim öğretmenlerine uygulanan mentorluk programının ikinci yllına bakış. Journal of Human Sciences, 14(4), 3548-3570. doi:10.14687/jhs.v14i4.4930

Keywords: Autism spectrum disorders; göstermiştir. Ayrıca, programın eksik ve güçlü qualitative research; mentor; special education; yönlerine ilişkin katılımc1 görüşleri bulgularda teacher.

(Extended English abstract is at the end of this document) yer almıştır. Araştırmanın, çevrimiçi mentorluk programlarının planlanması ve yürütülmesi sürecine 1şık tutabileceği düşünülmektedir.

Anahtar Kelimeler: Mentor; nitel araştırma; otizm spektrum bozukluğu; özel eğitim; öğretmen.

\section{Giriş}

OSB sosyal-iletişim alanlarında güçlükler, takıntılı davranışlar, sınırlı ilgiler ve davranış sorunlar1 ile tanımlanmaktadır. (American Psychiatric Association, 2013; Chowdhury, 2009; Mehling ve Tasse, 2016). OSB tanılı bireylere sunulan eğitimler, OSB'nin özellikleri bağlamında, diğer yetersizlik gruplarındaki bireylere sunulan eğitimlerden farklılaşmaktadır. OSB tanılı bireylerin eğitimlerinde sosyal ve iletişim becerilerine özgü programlara ağırlı verilmesi, OSB’ye özgü müfredat kullanılması bu farklılıklardan bazılarıdır. Dolayısıyla, OSB tanılı bireylerle çalısan öğretmenlerin OSB'ye özgü bilgi ve becerileri içeren eğitimlere katılarak, gerekli mesleki yeterlilikleri kazanmış olmaları gerekmektedir. OSB'nin kendine özgü özellikleri ve OSB tanısının içinde yer alan bireylerin birbirlerinden oldukça farklı özellikler göstermeleri bağlamında, OSB özel bir uzmanlık alanı olarak ele alınmaktadır (Alexander, Ayres ve Smith, 2015; Eikeseth, 2010; Güleç-Aslan, 2014; Odom ve Connie, 2015). Ancak OSB tanılı bireylerle çalışan öğretmenlerin, farklı eğitim geçmişleri (özel eğitim öğretmenliği mezunları, özel eğitim sertifikalı branş öğretmenleri, vb.) olduğu görülmektedir. Bu programların ve/veya sertifika programlarının içeriklerinde ise belirli düzeyde bir standartlaştırmanın söz konusu olmadığı, içeriklerin birbirlerinden oldukça farklılaştığı dikkati çekmektedir. Bu öğretmenler, mezun oldukları programlar OSB’ye özgü olmadığından, OSB’ye ilişkin sınırlı ders alabildiklerinden ve bu derslerinde ağırlıklı olarak kuramsal bilgileri içerdiğinden; bir başka deyişle OSB'ye özgü bir eğitim sürecinden geçemediklerinden, OSB hakkında yeterli bilgi ve beceriye sahip olamadan işe başlamaktadırlar (Ergenekon, 2005, 2009; Güleç-Aslan ve SolaÖzgüç, 2017; Scheuermann, Webber, Boutot ve Goodwin, 2003). Bu nedenle de, özellikle mesleklerinin ilk yıllarında zorlanabilmektedirler. Bir başka deyişler, öğretmenlik mesleğine ve yeni bir ortama uyum sağlama çabalarının sergilendiği öğretmenlik mesleğinin ilk yılları, OSB olan öğrencilerle çalışan öğretmenler için diğer öğretmenlerden daha zor geçebilmektedir.(Billingsley, 2004; Dempsey, Arthur-Kelly ve Carty, 2009; Ergenekon, 2005, 2009; Ergül, Baydik ve Demir, 2013; Güleç-Aslan, 2014; Güleç-Aslan ve Sola-Özgüç, 2017; Hendricks, 2011; Kodal, 2006; Koegel, Matos-Fredeen, Lang ve Koegel, 2012; Litton, Rotatori, Coombs-Richardson ve Matinez, 2017; ).

OSB alanında çalısan öğretmenler ilk yıllarında sıklıkla öğretimsel (OSB tanılı bireylere yönelik öğretim programlarını uygulama, değerlendirme, vb.) ve davranış sorunları konularında güçlükler yaşamaktadırlar. Ayrıca, OSB'nin pek çok farklı alandan (tıp, dil ve konuşma terapisi, vb.) uzmanla işbirliğini gerektiren bir alan olmasından dolayı, diğer uzmanlarla koordinasyon sağlama ve işbirlikçi bir şekilde çalışma ile ilişkili sorunlar söz konusu olabilmektedir. Bunların yanı sıra, diğer ögrretmenlik alanlarında da görülen; okuldaki resmi ve yasal süreçlere uyum sağlamayla, yeni bir ortama girmenin getirdiği uyum güçlüklerinden kaynaklı duygusal güçlüklerle (yoğun kaygı yaşama, vb.), ailelerle iletişim kurmada karşllaşılabilen problemlerle ve özel eğitim alanına özgü görevlerin yanı sıra okuldaki çeşitli sorumlulukların (evrak işleri, vb.) getirdiği iş yüküyle getirdiği sorunlar bu öğretmenlerin mesleklerinin ilk yıllarında yaşadıkları sorunlara arasındadır (Billingsley, Israel ve Smith, 2011; Billingsley ve Cross, 1992; Elrod, Coleman, Shumpert ve Medley, 2005; Ergenekon, 2005, 2009; Güleç-Aslan ve Sola-Özgüç, 2017; Kodal, 2006; Mehrenberg, 2013 Scheuermann ve diğ., 2003). 
Güleç Aslan, Y., \& Sola Özgüç, C. (2017). Öğretmenliğin ilk yıllarında otizm spektrum bozukluk tanılı öğrencilerle çalışan özel eğitim öğretmenlerine uygulanan mentorluk programının ikinci yllına bakış. Journal of Human Sciences, 14(4), 3548-3570. doi:10.14687/ihs.v14i4.4930

OSB tanılı bireylerin öğretmenlerinin özellikle mesleklerinin ilk yıllarında yaşadıkları bu sorunlar mesleki tükenmişliğe, motivasyon düşüklüğüne ve iş doyumunda azalmaya yol açabilmektedir (Billingsley, 2004, Jennett, Harris ve Mesibow, 2003; Sebald ve Rude, 2015; Simpson, 2004). Bu tür sorunlarla baş edemeyen öğretmenler, öğrencilerine nitelikli bir eğitim sunmakta güçlükler yaşayabilmektedirler (Billingsley, 2004, Güleç-Aslan ve Sola-Özgüç, 2017). Ancak, otizm konusunda mesleki nitelikleri artan öğretmenler, özellikle mesleklerini ilk yıllarında yaşadıkları sorunlarla daha kolay baş edebilmektedirler ve böylece mesleki doyumları artarak, eğitim sundukları OSB tanılı birey ve ailelerini nitelikli bir eğitim sunmaktadırlar (Billingsley ve diğ., 2011; Jennett ve diğ., 2003; Sebald ve Rude, 2015; Simpson, 2004; ). Bu doğrultuda, bu öğretmenlere mesleklerinin ilk yıllarında sunulan destek hizmet programları kapsamındaki işe uyum programları bu öğretmenlerin bilgi ve becerilerinin gelişmesini sağlamaktadır. Böylece bu öğretmenlerin mesleki yeterlilikleri artmaktadır, yaşadıkları sorunlarla baş etmeleri kolaylaşmaktadır ve işe uyum süreçleri kolaylaşmaktadır (Barnhill, Polloway ve Sumutka, 2011; Brownel, Sindelar, Bishop, Langley ve Seo, 2002; Güleç-Aslan ve Sola-Özgüç, 2017; Litton ve diğ., 2017; Marder ve deBettencourt, 2012; Simpson, Sharon, Kan ve Qing Qing, 2016; Sulek, Trembath, Paynter, Keen ve Simpson, 2017). OSB tanılı bireylerle çalışan öğretmenlerin mesleklerinin ilk yıllarını başarılı bir şekilde geçirmeleri için önem taşıyan işe uyum programları; mesleki bilgi ve beceri kazandırma amaçlı hizmet sunma, mentorluk programları, danışmanlık sağlama, duygu paylaşımı odaklı grup çalışmaları sunma gibi çeşitli yollarla yürütülebilmektedir (Brownell ve diğ., 2002; Crisp ve Cruz, 2009; Ergenekon, 2005, 2009; Güleç-Aslan ve Sola-Özgüç, 2017; Smith ve Ingersoll, 2004; White ve Mason, 2006). Mesleğe yeni başlayan öğretmenlere yönelik işe uyum programlarında oldukça önem taşıyan mentorluk programları kapsamında, deneyimli bir öğretmen (mentor) tarafindan mesleğinin ilk yıllarındaki deneyimsiz öğretmene çeşitli hizmetler sunulmaktadır. Bu hizmetler, deneyimsiz öğretmene ihtiyac1 olduğu konularda bilgi ve beceri kazandırmayı ve/veya düzeyini arttırmayı, uyum sürecinden yaşayabileceği stres ve kaygı düzeyini azaltmayı, kurum sistemine ve kültürüne uyum sağlamayı, mesleki motivasyonu arttırmayı, kişisel ve mesleki gelişim sağlamayı, okul içindeki ve dışındaki öğretmenle, yöneticilerle, uzmanlarla ve ailelerle iletişim becerilerini geliştirmek kapsamaktadır. Bu doğrultuda, öncelikle mentorun hizmet alacak kişinin ya da grubun varolan sorunlarını, ihtiyaçlarını saptaması ve hizmet alacak kişinin ya da grubun görüşleri doğrultusunda bir mentorluk hizmet planı oluşturması gerekmektedir (Billingsley ve diğ., 2011; Gentry, 2016; Güleç-Aslan ve Sola-Özgüç, 2017; Israel, Kamman, McCray ve Sindelar, 2014; Jones, De Kock, Charles, Jourdan, Copeland ve Willis, 2015; Manzar-Abbass, Malik, Khurshid ve Ahmad, 2017; Sebald ve Rude, 2015). Mentorluk programlarındaki bu tür hizmetlerin yürütülmesinde yaygın olarak üç mentorluk modeli söz konusudur. Birebir mentorluk (one to one mentoring) en sik kullanilan mentorluk modeli olup, mentor ve deneyimsiz öğretmen çiftleri oluşturularak, mentor tarafindan bireysel olarak hizmet sunulmasını içermektedir. Diğer bir model bir ya da daha fazla mentor ile deneyimsiz öğretmenlerden oluşan bir grup arasındaki hizmet alıp verme süreci kapsayan grup mentorluk (group-team mentoring) modelidir. Son olarak, mesleklerinin ilk yıllarındaki akran öğretmenlerin sorunlarını paylaşarak, bu sorunlarla başa çıkmada birbirlerine yol göstermelerini kapsayan akran mentorluğu (peer mentoring) modeli söz konusudur. Bu modellerden birbirlerinden bağımsız olarak tek bir model olarak kullanılabileceği gibi mentorluk modelleri bir arada da kullanılabilmektedir (Crisp ve Cruz, 2009; DeWert, Babinski ve Jones, 2003; Güleç-Aslan ve Sola-Özgüç, 2017; Kuzu, Kahraman ve Odabaşı, 2012). Hangi mentorluk modeli kullanılırsa kullanılsın, mentorun uzmanlık alanı ile deneyimsiz öğretmenin alanının benzer olmasına dikkat edilmelidir. Ayrıca, mentorun etkili iletissim becerilerine sahip olması, uygulama deneyiminin olmas1 ve etik kurallara uygun davranmas1 gerekmektedir (Güleç-Aslan ve Sola-Özgüç, 2017; Jones, ve diğ., 2015; Smith ve Israel, 2010; Whitaker, 2000). Mentorluk programlarında mentorlar tarafindan sunulan hizmetler mentorun sinıf içinde ve veya sınıf dışında deneyimsiz öğretmenle yüz yüze çalışmasına dayalı olarak yürütülebilmektedir. Ancak, günümüzde teknolojinin eğitim-öğretim ortamlarında yaygın ve etkili olarak kullanımı çevrimiçi mentorluk (online mentoring) programlarını ön plana çıkarmıştır. Bu 
Güleç Aslan, Y., \& Sola Özgüç, C. (2017). Öğretmenliğin ilk yıllarında otizm spektrum bozukluk tanılı öğrencilerle çalışan özel eğitim öğretmenlerine uygulanan mentorluk programının ikinci yllına bakış. Journal of Human Sciences, 14(4), 3548-3570. doi:10.14687/jhs.v14i4.4930

doğrultuda, e-postalar, web siteleri ve bloglar aracilğ̆yla çevrimiçi mentorluk programları kapsamında pek çok hizmet sunulmaktadır (Gentry, 2016; Güleç-Aslan ve Sola-Özgüç, 2017; Kuzu ve di⿱̆. ., 2012; White ve Mason, 2006).

Genel eğitim öğretmenlerine yönelik mentorluk programlarının mesleğinin ilk yıllarındaki öğretmenlerin işe uyumlarını kolaylaştırarak mesleğin ilk yıllarını başarılı geçirmelerini sağladığına yönelik araştırma bulguları söz konusudur (örneğin, Andrews ve Quinn, 2005; Babione ve Shea, 2005; DeWert ve diğ., 2003; Harrison, Lawson ve Wortley, 2005; Manzar-Abbass, ve diğ., 2017). Ancak, her ne kadar alanyazında mesleklerinin ilk yıllarında OSB tanilı bireylere hizmet sunan öğretmenlere yönelik mentorluk programlarının önemi vurgulansa da (Barnhill ve diğ., 2011; Boyer ve Lee, 2001; Ergenekon, 2005, 2009; Güleç-Aslan ve Sola-Özgüç, 2017), bu öğretmenlere yönelik mentorluk programları ile ilgili araştırmaların sinırlılığ1 söz konusudur. Boyer ve Lee (2001) tarafindan gerçekleştirilmiş olan çalışma mesleğinin ilk yllında otizm tanılı öğrencilere $(n=6)$ eğitim sunan bir öğretmenin sorunlarına ve bu sorunlara yönelik mentorluk programına yöneliktir. $\mathrm{Bu}$ çalışmada, ikinci yazar olan öğretmenin yaşadığı sorunlar ve çalıştığı okulda sunulan mentorluk programı hakkındaki betimleyici bilgiler sunmuştur. Öğretmen mesleğinin ilk y1lında bürokrasi ve yasal süreçleri anlamak, BEP hazırlamak, otizmi olan öğrencilere yönelik öğretim ve davranış değiştirme yöntemleri gibi konularda sorunlar yaşadığını ve bir mentor aracıllı̆̆ıyla yürütülen mentorluk programının bu sorunlarla baş etmesini ve mesleğinin ilk yılının başarılı geçmesini sağladığı belirtilmiştir. Diğer bir araştırmada, özel eğitim öğretmenleri (n=15) tarafından, farklı eğitim geçmişleri olup, özel eğitim alanında yüksek lisans yapan 37 stajyer öğretmene OSB içerikli mentorluk programı nitel olarak incelenmiştir. Program, kuramsal ve uygulamalı olarak yürütülmüştür. Uygulama kayıtlarından, çalışmalara ilişkin yansıtma notlarından ve stajer öğretmenlerin geribildirimlerinden oluşan verilerin analizi, mentorlar tarafindan sunulan hizmetlerin stajer öğretmenlere sinıflarında öğretimi planlama ve yürütme açısından yardımcı olduğunu ortaya koymuştur (Parker-Katz ve Hughes, 2008). Marder ve deBettencourt (2012) tarafindan gerçekleştirilen diğer bir nitel çalışmada ise, OSB’ye yönelik dersleri içeren bir çevrimiçi lisansüstü programının sonuçları betimlenmiştir. Programa katılan 12 özel eğitim öğretmeninin iki tanesi mesleğinin ilk yılındadır. Programdan mezun olan öğretmenler, program aracilığıyla güncel bilgileri edindiklerini ve programın sınıflarında çeşitli öğretim etkinlikleri planlayarak, bu planları yürütebilmelerinde faydalı olduğunu ifade etmişlerdir. Türkiye'deki alanyazın incelendiğinde, mesleğinin ilk yıllarında OSB tanılı öğrencilerle çalışan öğretmenlerin sorunlarına ve bu öğretmenlere sunulan destek hizmetler kapsamındaki işe uyum programlarına ve özellikle de mentorluğa yönelik sınırlı sayıda araştırma görülmektedir. Ergenekon $(2005,2009)$ tarafindan 17 öğretmen ile yürütülen nitel araştırmada, mesleğin ilk yllındaki zihin engelliler öğretmenliğinden (Z.E.Ö.) mezun öğretmenlerin yaşadıkları sorunlar saptanmıştır ve bu sorunların giderilmesine yönelik öneriler ortaya konmuştur. Katılımcı öğretmenlerden sadece bir tanesi bir tanesi Otistik Çocuklar Eğitim Merkezi (OÇEM)'de çalışmaktadır. Diğer katılımcılar ise zihinsel engelli öğrencilerle çalışmaktadırlar. Araştırma bulguları, öğretmenlerin davranış ve sınıf kontrolü, aile ile ilişki, uzman işbirliği, okula ve çevreye uyum sağlama, öğretimle ilgili konular ve bürokratik işlerle ilgili sorunlar yaşadıklarını göstermiştir. Öğretmenler kendilerine sunulan adaylık eğitimi programının yararlı olduğunu belirtmelerine rağmen, bu tür eğitimlerin özel eğitim alanda deneyimli öğretmenler tarafından, uygulamalı olarak verilmesine yönelik görüşlerini belirtmişlerdir. Araştırma bulguları temelinde, öğretmenlerin ilk yıllarının başarılı geçmesi için işe uyum programlarının faydalı olacağ1 vurgulanmıştır. Diğer bir nitel araştırmada ise, otizm tanısı olan öğrencilerle çalışan özel eğitim öğretmenlerinin sorunları, görüşmeler aracıllŏgyla saptanmıştır. Katılımcılar, Z.E.Ö. ya da başka bölüm mezunu olan ve Z.E.Ö. alanında yüksek lisans yapmış olan 16 öğretmen olup, yedi tanesi mesleklerinin ilk ya da ikinci yllındadır. Bulgular öğretmenlerin eğitimleri süresince otizmle ilişkili bir ders almadıklarını, öğretim sunma ve davranış kontrolü konularında zorlandıklarını ve otizm ile ilgili kuramsal ve uygulamalı destek hizmetlere ihtiyaçları olduğunu ortaya koymuştur (Kodal, 2006). Güleç-Aslan ve Sola-Özgüç (2017), tarafından gerçekleştirilen nitel vaka 
Güleç Aslan, Y., \& Sola Özgüç, C. (2017). Öğretmenliğin ilk yıllarında otizm spektrum bozukluk tanılı öğrencilerle çalışan özel eğitim öğretmenlerine uygulanan mentorluk programının ikinci yılına bakış. Journal of Human Sciences, 14(4), 3548-3570. doi:10.14687/ihs.v14i4.4930

araştırmasında ise, mesleklerinin ilk yılında OSB alanında çalışmaya başlayan Z.E.Ö. bölümü mezunu öğretmenlerin yaşadıkları sorunların saptaması ve bu sorunların çözümüne yönelik oluşturulan bir çevrimiçi mentorluk programının planlama ve yürütülme süreci incelenmiştir. Katılımcilar, bir devlet üniversitesinin Z.E.Ö. bölümünden 2012 yılında mezun olan ve OSB tanıl1 öğrencilerin bulunduğu okullarda göreve başlayan beş öğretmendir. Katıllmcıların karşılaştıkları sorunlarını, görüşlerini ve araştırmacıların da önerilerini bildirmeleri için bir e-posta grubu oluşturularak, bir çevrimiçi mentorluk çalışması başlatılmıştır. Araştırmanın bulguları, katılımcı öğretmenlerin temel olarak öğretim sunma, davranış değiştirme ve okul sistemine ilişkin çeşitli konuları anlama (idari işler, vb.) bağlamında sorunlar yaşadıklarını; bu sorunların çözümüne yönelik desteğe ihtiyaçları olduğunu ortaya koymuştur. Katılımcılar ilk yıllarında kendilerine otizm konusunda deneyimli bir eğitimci, hatta mezun oldukları bölümün öğretim elemanlarınca sunulacak kuramsal bilgiye ve uygulamaya dayalı olarak yürütülecek mentorluğu içeren işe uyum programlarının sorunların çözümünde ve uyum sağlamalarında faydalı olacağını bildirmişlerdir. Ayrıca, bu tür hizmetlerin içeriğinin oluşturulmasında, kendilerinin bildirdikleri sorunların ve çözüm önerilerinin dikkate alınmasını gerektiğini vurgulamışlardır. Bulgulara göre, katılımcılar bu hizmetlerin sadece bilgi ve beceri geliştirme amaçlı olmayıp, kişisel gelişimlerine ve psikolojik uyumlarına katkı sağlayıcı bir nitelik taşımasının önemini belirtmişlerdir. Araştırmada öğretmenlerin önerileri doğrultusunda, araştırmacılar tarafindan pilot uygulama niteliğinde bir çevrimiçi mentorluk programı programının planlama ve yürütme sürecinin incelenerek, sonraki yıllarda uygulanabilecek kapsamlı mentorluk programlarının geliştirilmesi için temel olabilecek bulgular edinilmiştir. Bulgulara göre, e-posta grubu araciluğıly çevrimiçi olarak sunulan mentorluk programının içeriği, otizm alanındaki kuramsal bilgi sunumunun yanı sıra, kişisel gelişim, duygusal destek ve motivasyon, öğretmenlerin uygulamalarına ilişkin geribildirim sunma, materyal geliştirme gibi çeşitli konuları da kapsamıştır. Grup mentorluğu ve akran mentorluğu modelleri temelindeki programın yürütülmesi sürecinde öğretmenler program süresince üzerinde durulan konulardaki (öğretim yöntemleri, motivasyon, vb.) uygulamalarında sorun yaşamadıklarını ve uygulamalarında olumlu sonuçlar almaya başladıklarını belirtmişlerdir. Bulgular, katılımcıların ve araştırmacıların yürütülen çevrimiçi mentorluk programını var olan katılımcılara, aynı üniversitenin Z.E.Ö. bölümünden mezun olup, OSB'li öğrencilerin devam ettiği okullarda çalışmaya başlayacak öğretmenlerin de katılımıyla devam etmesi yönünde karar alındığını içermektedir.

Yukarıdaki bilgilerde de görüldüğ̈̈ üzere, mesleğin ilk yıllarında OSB olan öğrencilerle çalışan öğretmenlere yönelik mentorluk programlarının, bu öğretmenlerin ilk yıllarının başarılı geçmesi için önemli olduğu vurgulansa da, bu konuda sınırlı sayıda araştırma söz konusudur. Oysa, bu öğretmenlerin ihtiyaçları ve sorunları temelinde hazırlanan mentorluk programlarının, nitel araştırmalarla incelenmesi nitelikli mentorluk programlarının ortaya konması için önem taşımaktadır (Ergenekon, 2005, 2009; Güleç-Aslan ve Sola-Özgüç, 2017; Parker-Katz ve Hughes, 2008; Marder ve deBettencourt, 2012). Alanyazında da, mesleklerinin ilk yıllarında OSB’li öğrencilerle çalışan öğretmenlerin sorunlarını ve sorunların çözümüne yönelik mentorluk programlarının planlanma ve yürütülme süreci ile sonuçlarının incelendiği nitel araştırmalara gereksinim olduğunu bildirilmektedir (Alber ve Nelson, 2002; Babione ve Shea, 2005; Boardman, Argüelles, Vaughn, Hughes ve Klinger, 2005; Carpenter, 2007; Ergenekon, 2005, 2009; Güleç-Aslan ve Sola-Özgüç, 2017).

Bu doğrultuda, Güleç-Aslan ve Sola-Özgüç (2017) tarafından gerçekleştirilmiş olan araştırmanın bulguları ve önerileri bağlamında, araştırmanın devamı niteliğindeki bu araştırma yürütülmüştür. Araştırmanın amacı, mesleğinin ilk yıllarını OSB alanında çalışan Z.E.Ö. bölümü mezunu öğretmenlere yönelik geliştirilmiş bir çevrimiçi mentorluk programının ikinci yılının nitel olarak incelenmesidir. Bu temel amaç bağlamında cevap aranan sorular şöyledir: 1. Mesleğinin ilk yıllarını OSB alanında çalışan Z.E.Ö. mezunu öğretmenlere yönelik çevrimiçi mentorluk programının içeriği nasıldır?, 2. Mesleğinin ilk yıllarını OSB alanında çalışan Z.E.Ö. mezunu öğretmenlere yönelik çevrimiçi mentorluk programının faydalarına ilişkin katılımcıların görüşleri nelerdir?, 3. Mesleğinin ilk yıllarını OSB alanında çalışan Z.E.Ö. mezunu öğretmenlere yönelik 
Güleç Aslan, Y., \& Sola Özgüç, C. (2017). Öğretmenliğin ilk yıllarında otizm spektrum bozukluk tanılı öğrencilerle çalışan özel eğitim öğretmenlerine uygulanan mentorluk programının ikinci yllına bakış. Journal of Human Sciences, 14(4), 3548-3570. doi:10.14687/jhs.v14i4.4930

çevrimiçi mentorluk programının eksik ve güçlü yönlerine ilişkin katılımcıların görüşleri nelerdir? $\mathrm{Bu}$ araştırmanın, mesleğin ilk yıllarındaki öğretmenlerin ilk yıllarını olumlu geçirebilmeleri amacıyla, onlara sunulacak çevrimiçi mentorluk programlarının planlanması ve yürütülmesi sürecine ışık tutabileceği düşünülmektedir. Ayrıca, konuyla ilgili sınırlı alanyazına da katkıda bulunması umulmaktadır.

\section{Yöntem}

\section{Araştırmanın Modeli}

Araştırma nitel araştırma yöntemlerinden vaka çalışması ile yürütülmüştür. Bir programın planlama ve yürütülme sürecinin incelenerek, sonraki uygulama ve araştırmalara yol gösterme amaçlı çalışmalarda vaka çalışması uygulanmaktadır (Creswell, 2014; Yıldııım ve Şimşek, 2008).

\section{Araştırmanın Katılımcılar}

Araştırmanın katılımcıları bir devlet üniversitesinin Z.E.Ö. lisans programından mezun olup, sadece OSB'li öğrencilerin bulunduğu özel eğitim uygulama merkezleri ve bağımlı Otistik Çocuklar Eğitim Merkezlerinde (OÇEM) göreve başlayan yedi öğretmendir ( $K=6, E=1)$. Öğretmenlerden beşi mesleğinin ikinci yllında olup, Güleç-Aslan ve Sola-Özgüç (2017) tarafindan gerçekleştirilmiş olan araştırmadaki çevrimiçi mentorluk programına katılan öğretmenlerdir. İki öğretmen ise, henüz mesleklerinin ilk yılindadırlar.

Tablo 1'de görüldüğü üzere, katılımcıların beş tanesi sadece otizmi olan öğrencilerin devam ettiği Özel Eğitim Uygulama Merkezinde (Otistik Çocuklar Eğitim Merkezi/OÇEM), ikisi ise kaynaştırma eğitimi kapsamında genel eğitim okulları bünyesinde otizmli öğrenciler için açılan özel eğitim sınıfları olan bağımlı OÇEM'lerde görev yapmaktadır. Yaş aralığı 24-27 olup, yaş ortalaması ise 24'tür.

Araştırma katılımcılarının seçiminde tipik durum örneklemesi kullanılmıştır. Tipik durum örneklemesi, üzerinde çok fazla araştırma olmayan konuların ve yeni programların incelenmesine yönelik araştırmalarda sıklıkla kullanılmaktadır. Örneklem seçiminde, bu tür durumları temsil edebilecek en tipik bir ya da birkaç tipik durum seçilerek, çalışma yürütülür (Patton, 1987; Yıldırım ve Şimşek, 2008). Bu araştırma katılımcılarının mezun olduğu üniversitenin Z.E.Ö. bölümü kapsamında yürütülmeye başlanmış olan çevrimiçi mentorluk programı geliştirme çalışmaları devam etmekte olduğundan, bu üniversite tipik bir durum olarak ele alınmıştır. Bu doğrultuda, bu bölümden mezun olup, OSB'li öğrencilerin bulunduğu kurumlarda öğretmenliklerinin ilk ve ikinci yıllarını yürüten mezunlara $(\mathrm{N}=8)$ araştırmanın amacı hakkında bilgi vermiştir. Yedi öğretmen araştırmada yer almak istediklerini sözel ve yazılı olarak bildirmiştir. Mesleğinin ilk yllındaki bir öğretmen ise çalışmada yer almak istememiştir. Araştırma etiği doğrultusunda katılımcıların kimlikleri gizli tutulmuştur (Yıldırım ve Şimşek, 2008).

\section{Tablo 1. Katılımcı Özellikler}

\begin{tabular}{ccccc}
\hline Kathlımcılar & Cinsiyet & Yaş & Mezuniyet Y1lı & Okul Türü \\
\hline 1 & $\mathrm{~K}$ & 24 & 2012 & Bağımlı O̧EM \\
2 & $\mathrm{~K}$ & 25 & 2012 & Özel Eğitim Uygulama Merkezi \\
3 & $\mathrm{~K}$ & 23 & 2012 & Özel Eğitim Uygulama Merkezi \\
4 & $\mathrm{~K}$ & 24 & 2012 & Özel Eğitim Uygulama Merkezi \\
5 & $\mathrm{E}$ & 27 & 2012 & BağımlıÇEM \\
6 & $\mathrm{~K}$ & 24 & 2013 & Özel Ë̆itim Uygulama Merkezi \\
7 & $\mathrm{E}$ & 24 & 2013 & Özel Ĕ̈itim Uygulama Merkezi \\
\hline
\end{tabular}


Güleç Aslan, Y., \& Sola Özgüç, C. (2017). Öğretmenliğin ilk yıllarında otizm spektrum bozukluk tanılı öğrencilerle çalışan özel eğitim öğretmenlerine uygulanan mentorluk programının ikinci yllına bakış. Journal of Human Sciences, 14(4), 3548-3570. doi:10.14687/ihs.v14i4.4930

\section{Çevrimiçi mentorluk programının yürütülme süreci}

Araştırma boyunca yürütülen çevrimiçi mentorluk programı, grup-mentorluk ve akran mentorluk şeklinde yürütülmüştür. Bu doğrultuda araştırmacılar mentor olarak görev almışlardır. Mentorlardan bir tanesi, bir devlet üniversitesinin Özel Eğitim Bölümü Zihin Engelliler Öğretmenliği programında çalışmaktadır. OSB alanında uygulamalı ve kuramsal çalısmalar yürütmektedir. İkinci mentor ise, bir devlet üniversitesinin Özel Eğitim Bölümü Zihin Engelliler Öğretmenliği programında çalısmaktadır. Özel eğitimde teknoloji kullanımı, özel eğitim öğretmenlerinin teknoloji kullanımları ve otizm alanında çalışmaları bulunmaktadır. Programın sadece mentorların katılımcılara hizmet sunduğu bir program olarak değil, aynı zamanda katılımcıların da kendi yaşadıkları soruların çözümünde etkin olarak rol aldıkları bir program şeklinde yürütülmesi hedeflenmiştir. Bu doğrultuda, program kapsamında hem mentorlar katılımcılara, hem de akran katılımcılar birbirlerine daha önce kurulmuş olan e-posta grubu (GüleçAslan ve Sola-Özgüç (2017) aracilığiyla yol göstermişlerdir. Bir başka deyişle, bu e-posta grubu aracılığılla, hem mentorların katılımcılarla etkileşim içinde bulunduğu grup mentorluk modeli, hem de katılımcıların sorunlarını, duygularını, ihtiyaçlarını paylaşarak birbirlerine destek olmasını ve birbirlerine önerilerde bulunmasını kapsayan akran mentorluğu modeli bağlamında çevrimiçi mentorluk çalışmaları yürütülmüştür. Program, katıllımcıların belirttikleri ihtiyaçlar temelinde 15 günde bir belirlenen içerik bağlamında, e-posta grubunda paylaşımda bulunularak yürütülmüştür. Katılımclar ve mentorlar belirlenen içerikle ilgili olarak kendi deneyimlerini, önerilerini ve görüşlerini sunmuşlardır. Bu içerikle ilişkili önerilerde bulunmuşlardır, materyaller (örneğin uygulama videosu, makale) paylaşmıslardır ve mentorlar katılımcıların sorularını cevaplamışlardır. Ayrıca katılımcılarda sorulan sorulara dair kendi bilgilerini paylaşmışlardır. Böylece her bir konuyla ilişkili olarak uygulama sürecinde yaşanan sorunların çözümüne yönelik paylaşımlarda bulunulmuştur. Mentorlar paylaşımın yanı sıra katılımcıların ihtiyaçları çerçevesinde yol gösterici önerilerini materyal desteği (videolar, makaleler, uygulama notları, vb.) sağlayarak sunmuşlardır. Bu süre boyunca eğer katımcıların paylaşmak istedikleri yeni bir içerik oluşmuşsa bu içerik de programa eklenmiştir. Yeni içeriklerin görüşülmesi devam ederken bir önceki içerikle ilgili katıllımcıların uygulamaları ve görüşleri tartışılmaya devam etmiştir. Ayrıca, bazı içerikler katılımcıların talebi doğrultusunda iki haftadan fazla görüşülmüştür. E-posta grubunun yanısıra, özellikle acil bir ihtiyaç durumunda telefon aracıllğıyla da iletişim sağlanmıştır.

\section{Veri Toplama Süreci}

Çalışmanın verileri, Ekim 2013-Nisan 2014 tarihleri arasında, kişisel bilgi formu, süreç ürünleri, görüş formu ve araştırmacı günlükleri ile toplanmıştır. Araştırma katılımcıları ile halen ihtiyaçları doğrultusunda e-posta ve telefon görüşmeleri doğrultusunda paylaşımlar devam etmektedir.

Kişisel Bilgi Formu: Katılımcıların yaş, cinsiyet, mezuniyet, mesleki kıdem gibi bilgilerini edinmek amacıyla, bu konularda bilgi toplamayı amaçlayan kişisel bilgi formu hazırlanarak, katıllmcılara uygulanmıştır.

Süreç Ürünleri: Katılımcıların yaşadıkları sorunları, ihtiyaçlarını, program içeriğindeki konulara ilişkin görüşlerini ve önerilerini bildirmeleri amacıyla araştırmacılar tarafindan bir e-posta grubu oluşturulmuştur. Süreç ürünleri, mentorluk programı süresince e-posta grubuna yazilan epostalardır. Bu e-postalar ile araştırmanın verileri toplanmışır.

Görüş Formu: İki sorudan oluşan bu form, araştırma katılımcılarının mentorluk programını değerlendirmeleri amacıyla, katılımcıların programın katılımcılara katkılarını ve programın daha faydalı olması için önerileri bağlamında görüşlerini kapsamaktadır. Bu doğrultuda, görüş formu katılımcıların bu iki konudaki görüşleriniyansıtan kısa notları içermektedir. Program sonunda katılımcılardan bu formu doldurup, e-posta aracıllğ̆yla göndermeleri istenmiştir. 
Güleç Aslan, Y., \& Sola Özgüç, C. (2017). Öğretmenliğin ilk yıllarında otizm spektrum bozukluk tanılı öğrencilerle çalışan özel eğitim öğretmenlerine uygulanan mentorluk programının ikinci yllına bakış. Journal of Human Sciences, 14(4), 3548-3570. doi:10.14687/jhs.v14i4.4930

Araştırmacı Günlüğ̈: Mentorluk programı uygulama süreci boyunca araştırmacılar izlenimlerini, yorumlarını, öznel görüşlerini ve telefon görüşmesi gibi resmi olmayan görüşmeleri günlüklerine not etmişlerdir.

\section{Verilerin Analizi}

$\mathrm{Bu}$ araştırmada, betimsel analiz kullanılmıştır. Betimsel analizde, araştırma verilerinin sistematik bir şekilde incelerek verilerin özgün hallerinin kolayca anlaşllır bir düzende okuyucuya sunulması hedeflenmektedir. Betimsel analizde amaç, ham verilerin sistematik ve tematik bir akış açısıyla okuyucuya sunulması hedeflendiğinden, veriler ve bulgular birbirine benzemektedir. (Creswell, 2014; Özdemir, 2010; Yıldırım ve Şimşek, 2008). Bu araştırmada da, öncelikle veriler araştırmacılar tarafindan okunarak incelenmiştir. Birinci araştırmacı verileri araştırma amaçları doğrultusunda temalandırmıştır ve her iki araştırmacı bu temalar üzerinde uzlaşmışlardır. Uzman görüşü sonrası son hali verilen temalar doğrultusunda veri setleri tekrar incelenmiştir. Doğrudan alıntılar tematik bir bakış açısıyla tablolara aktarılmıştır. Bulgular, ilgili alanyazın çerçevesinde yorumlanarak okuyucuya aktarılmıştır.

\section{Geçerlik ve Güvenirlik}

Alanyazındaki bağlamında bu araştırmada şu önlemler söz konusudur (Brantlinger, Jimenez, Klingner, Pugach ve Richardson, 2005; Yıldırım ve Şimşek, 2008): (a) Veri toplama yöntemlerinde çeşitleme yapılmıştır, (b) katılımcıların kimlikleri gizlenmiştir, (c) her iki araştırmacı da araştırma verilerinin araştırma amaçları doğrultusunda temalandırılmasında uzlaştıktan sonra, bir alan uzmanına danışmışlardır. Alan uzmanı bir üniversitenin Özel Eğitim Bölümünde öğretim üyesidir ve doktora tezini nitel araştırma yöntemi ile yürütmüştür. Alan uzmanı, araştırma amacı, ham veriler ve betimsel analiz bağlamında araştırma soruları temel alınarak temaların oluşturulmasının uygun olduğu yönünde onay vermiştir, (d) temalarla verilerin tutarlllı̆̆ için ise aynı uzmana tematik bir bakış açısıyla veri setlerinden oluşturulmuş olan tablolar gönderilmiştir. Tablolar, temalar ve temalara ilişkin veri içeriklerinden oluşmaktadır. Alan uzmanından bu tabloları temalarla veri içeriklerinin uyumu bağlamında incelemesi istenmiştir. Alan uzmanının incelemesinden sonra, veri içerikleri temalarla uyum bağlaminda son kez kontrol edilerek, temalarla verilerin uyumu sağlanmıştır, (e) bulguların yorumlanması ilgili alanyazın bağlamında gerçekleştirilerek, veriler ile alanyazın arasında bir tutarlılık sağlanmıştır., (f) katılımcılara araştırmanın amacı ve bulgular ile ilişkili sözel ve yazılı bilgilendirme yapılmıştır. Böylece, teyidleri alınmıştır.

\section{Bulgular}

Araştırmanın bulguları, üç tema ve bu temalarla ilişkili doğrudan alıntıların yer aldığ1 tablolarda betimsel olarak sunulmuştur. Bu temalar şöyledir: Çevrimiçi mentorluk programının içeriği, çevrimiçi mentorluk programının faydaları ve çevrimiçi mentorluk programının eksik ve güçlü yönleri.

\section{Tema 1: Çevrimiçi mentorluk programın içeriği}

Bulgular doğrultusundaki ilk tema çevrimiçi mentorluk programının içeriğidir. Tablo-2'de görüldüğ̈ üzere program içeriği; oryantasyon, öğrenciyle etkileşim, Alternatif ve Destekleyici İletişim Sistemleri (ADİS), ifade edici dil, takıntılı davranışlar, kurs, seminer ve kongre, öğretim yöntemleri ve yazılı materyal paylaşımı olmak üzere sekiz konudan oluşmuştur. Bu konular programın yürütülme planı çerçevesinde, katılımcıların $(\mathrm{N}=7)$ ihtiyaçları doğrultusunda belirlenmiştir. Belirlenen konu 15 gün boyunca ele alınmıştır. Katılımcıların talebi doğrultusunda takıntılı davranışlar ve ifade edici dil konuları bir ay boyunca gündemde kalmıştır. Tablo-2'de konulara ilişkin örnek alıntılar yer almaktadır. 
Güleç Aslan, Y., \& Sola Özgüç, C. (2017). Öğretmenliğin ilk yıllarında otizm spektrum bozukluk tanılı öğrencilerle çalışan özel eğitim öğretmenlerine uygulanan mentorluk programının ikinci yllına bakış. Journal of Human Sciences, 14(4), 3548-3570. doi:10.14687/jhs.v14i4.4930

\section{Tema 2: Çevrimiçi mentorluk programının faydaları}

Programa katılan öğretmenler programın faydalarına ilişkin olarak aşağıda sunulan çeşitli görüşlerini bildirmişlerdir.

Mesleki yeterliliklerin gelişmesi: Öğretmenlerin tümü $(\mathrm{N}=7)$ bu programın mesleki yeterliliklerin gelişiminde katkı sağladığını bildirmişlerdir. Öğretmenlerin tamamı otizmi olan öğrencilerle çalışırken karşılaştıkları çeşitli sorunlarla baş etmelerinde bu programdan faydalandıklarını şu tür örnek cümlelerle ifade etmişlerdir:

"Bu program kendimi otizmi olanlarla çalssırken güvende hissetmemi sağladı hep. Cünkü bir sorun olduğunda paylaşacağım ve işe yarayan öneriler sunan bir gruba ait olduğumu biliyorum. Özellikle bas edemediğim sorunlar yaşad̆ğmda sunulan pratik öneriler işime yaradı." (Öğretmen-5, görüş formu), "ögretmen olup olmaz bu tür bir programdan destek aldiğrm için kendimi çok sansh görüyorum. Keske tüm ögrretmenler ama özellikle otizmde çalssanlar bu tür destekler alsa. Cünkü spesifik olarak otizme yönelik az ders gördük ve bu konu diğer gruplardan farklh, bu çocuklar daha farkl. Onun için bölümde gördïklerimiz, bazen yeterli olmuyor ve ayruca zaten teorik bilgizi uygulamak çok zor zaman laz̧m ve destek olup yol gösterecek birileri lazım. Bildiklerimi uygularken emin olmadiğım konularda hemen yol gösterecek birilerinin olması bildiklerimi uygulamam kolaylaștird. Ya da bazen emin olamıyorum doğru mu uyguladım. Geribildirim almake cok isse yarad. Bu program bunlar sağladiğ için çok faydalandim." (Öğretmen-6, görüş formu), "geçen sene de bu sene de çok faydalandim. Bildiklerim pekişti ve uygulamaya aktarmam daha kolay oldu." (Öğretmen-1, süreç ürünü), "okula ilke başladı̆ğmı zamanlar doğrusu kendime olan güvenim yeterli düzeyde değildi. Herbangi bir sorun karssisinda aslinda ne yapmam gerektigini biliyordum ama sanki hafizam sifurlanmıs

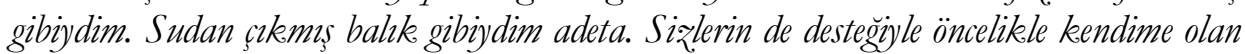
güvenim yerine geldi, olası bir olumsuz. durumla nasul başa çlkmam gerektiğini alternatif yöntemler de kullanarak aşabileceğimi fark ettim, annda geri dönütler olduğu için önerdiğini yö̈ntemleri de vakit kaybetmeden uygulama şansımı olduğu için çok daha hræl yol alabildik." (Öğretmen-4, görüş formu).

Öğretmenlerin tümü bu program ile otizm konusundaki bilgilerinin ve becerilerinin arttığını belirtmişlerdir. Öğretmenlerin görüşlerinden bazı örnek ifadeler şöyledir:

"Otizm ile ilgili sorularm olduğunda, örneğin çok iyi bilmediüzm bir ögretim yöntemi gibi sorularm olduğunda da bu program bana yardima oldu. Otižm alan beni biraz. korkutuyordu ama simdi alștım ve rahatım. Bu programin etkisi büyük.." (Öğretmen-1, görüş formu), "ayruca takintılarla bass etmemde de çok faydalı oldu." (Öğretmen-6, görüş formu), "ayruca bilmediğim konular ya da az, bildiğim konular vardi. Onlarla ilgili konustuklarmm, gönderilen makaleler, videolar çok faydah oldu. Kendi basıma olsam belki bunlar edinemezdim ya da arasturmazdim." "(Öğretmen-4, görüş formu), "bu yazıșmalarımı beni rahatlatyor ve zorlandiğım konularda bana yardimc olacak kişilerin olmasi, bilgiler sunulması çok güven veriyor."(Öğretmen-6, süreç ürünü), "kendimi yeterli bulamadĭğm konularda çok fayda gördüm." (Öğretmen-4, görüş formu), "ben çok fą̧a paylaşımda bulunamasam da yaz̨lanlardan cok faydalandım. Otiẓm konusunda az sey biliyordum Daha faそla bilgi kaz̧andım." (Öğretmen-7, süreç ürünü), "ayrnca hocam bilmenizi isterim ki ögrencilerimde yasanan gelismelerin çoğn sizin tavsiyeleriniz sayesinde çok teşekekür ederim siz̨e. Başarli olabilmemiz sizlerin sayesinde. Cünkü pek çok bilgimizi tazeledik ve bildiklerimizi uygulamaya geçirebildik. Bildiklerimi uygularken takuldiğm konularda bemen cevaplar alabilmem çok faydal oldu." (Öğretmen-5, süreç ürünü). 
Güleç Aslan, Y., \& Sola Özgüç, C. (2017). Öğretmenliğin ilk yıllarında otizm spektrum bozukluk tanılı öğrencilerle çalışan özel eğitim öğretmenlerine uygulanan mentorluk programının ikinci yllına bakış. Journal of Human Sciences, 14(4), 3548-3570. doi:10.14687/ihs.v14i4.4930

İşe uyum: Öğretmenlerin çoğunluğu (N=5) (Ö-1, Ö-2, Ö-4, Ö-5, Ö-6) programın işe uyumlarını kolaylaştırdığını belirtmişlerdir. Öğretmenler üniversiteden mezun olduktan sonra öğretmen olarak işe başladıkları kuruma ve okul sistemine ait konulara (bürokratik işler, yasalar, vb.) alışmalarında, iş arkadaşları, uzmanlar ve velilerle iletişim kurmayı öğrenmelerinde, iş yaşamına uyum sağlamalarında ve bu yeni durumun getirdiği psikolojik sıkıntılarla (kayg1, vb.) baş etmelerinde mentorluk programından faydalandıklarını bildirmişlerdir. Öğretmenlerin bazı örnek ifadeleri şöyledir:

"Sadece otizm ile ilgili değ̈l üniversite sonrasi is hayatına uyum să̆lama konusunda da fayda gördüm.”(Öğretmen-1, süreç ürünü), “hem alanla ilgili hem de kişisel ve diğer okul konularna alssmada. Örneğin, okulda yeni olduğum için anlamadrğım resmi konularda, meslektaslarla iliskilerde, vb. Aslinda her yönden faydal oldu."(Öğretmen-2, görüş formu), "okula ilk başladiğmmda çok tedirgin oldum. Universiteden sonra bir ögretmen olarak bir okula girmek sok farklyyd. Programm da desteğzyle rahat alıstım. Okuldaki bürokratik vb. işleri ögrenmemde ve pek cok konuda da fayda gördüm" (Öğretmen-6, süreç ürünü), "sadece ögrenciler değil aslında, ailelerle iletişim konusu olsun, meslektaşlarmmz ya da üstümüz ile iletişim konusunda da desteğinizi gördüm. Dolayısyla okulda kiminle nasil iletişim kuracağrz, nasıl davranacağrz, bunlara da alısmamı kolay oldu. Teşek.kür ediyorum. Psikolojik olarak çok iyi bir destekti bu grup. İlaç gibiydi. Cok zorlantp sikuldiğmda falan ilas gibi iyi geliyordu. Okula alısmama yardim etti." (Öğretmen-4, görüss formu), "üniversitede stajer olarak bulunduğumuz, okullara ögretmen olarak dönmek farkh. Bir sürü kural, diğer ögretmenlerle iletişim kurmak, bunlar zor. Birilerinin size destek olması güzeldi." (Öğretmen-5, süreç ürünü).

Mesleki doyum: Öğretmenlerden dört tanesi (Ö-1, Ö-4, Ö-5, Ö-6) ise bu programın mesleklerini daha çok sevmelerini ve otizm alanında çalışmaktan daha fazla keyif almaya başladıklarını şu örnek ifadelerle bildirmişlerdir:

"Önceden korkuyordum, sizlerin sayesinde otizm alanm daha cok sevmeye basladim. Kendimi otizmi olanlarla çalssırkeen güvende bissetmemi sağladu hep. Çünkü bir sorun olduğunda paylaşacağm ve isse yarayan öneriler sunan bir gruba ait olduğumu biliyorum." (Öğretmen-5, görüş formu), "öğrendikese otiž alanında çalıs̆may daha çok sevmeye başladım." (Öğretmen-4, süreç ürünü), "bu programlar ben hem otizmli çocuklarla çalısmayn hem de ögretmenlik yapmayz daha çok sevdim. Alustıkega daha keyif almaya başladım." (Öğretmen-1, süreç ürünü), "destek aldıkşa yaptı̆̆m işten aldiğm mutluluk artiyor.” (Öğretmen-6, süreç ürünü). 
Güleç Aslan, Y., \& Sola Özgüç, C. (2017). Öğretmenliğin ilk ylllarında otizm spektrum bozukluk tanıll öğrencilerle çalş̧an özel eğitim öğretmenlerine uygulanan mentorluk programının ikinci yllına bakıs. Journal of Human Sciences, 14(4), 3548-3570. doi:10.14687/ihs.v14i4.4930

\section{Tablo-2: Çevrimiçi mentorluk programının içeriği}

Konular

\section{Örnek alıntılar}

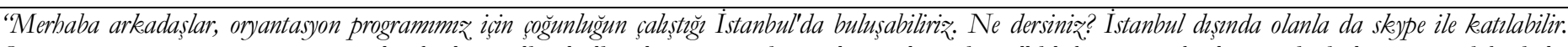

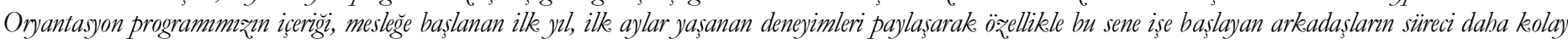
bir șekilde geçirmesini sağlamak.” (Mentor-2, süreç ürünü).

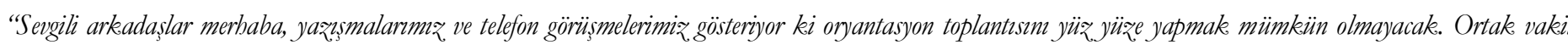
bulmak mümkün olmad. Dolayssyla önümïzdeki 15 günlük sürecte ve tabii ki sonrasinda konumuz ilk ynl ve ilk ay deneyimlerimizi pavlasmak, birbirimize

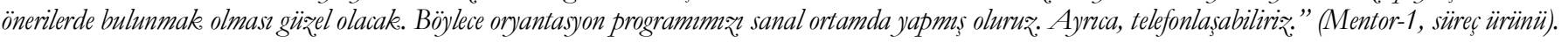

"Ben gecen sene ilk, basladiğrmda simıfta tek ögrencimin olmasindan ve onun da otizminin bafif olmasindan dolayı cok sanshydim. Buna rağmen ne yapacağım, nasıl

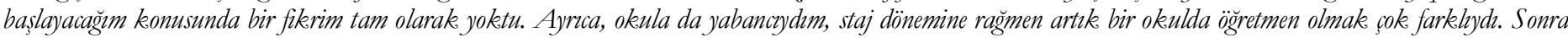

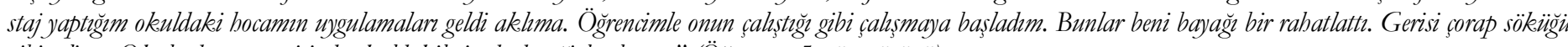
gibi geliyor. Okula da zaman içinde okuldakilerin de desteğizlle alsstım." (Öğretmen-5, süreç ürünü).

Oryantasyon

"Ben ilk ynhma başladiğrmda çocuklarmm çok iyi tanımadan çok fąla amaç almıstım ve bütün odak noktam nasil bütün bu amaçlar kazandırabilirim olmustu Zaman gectikse baktım ki amaclarmmn bic birini gerceklestiremiyorum bu durum beni psikolojik olarak cok etkilemeye basladn onlara yetemedigimi, sorunun bende olduğunu düşünüyordum. Aslinda, bana ilk zamanlardaki tüm süreçlerde destek olan birileri olsayde ber sey daha kolay olurdu.”(Ögrretmen-2, sürec ürünü).

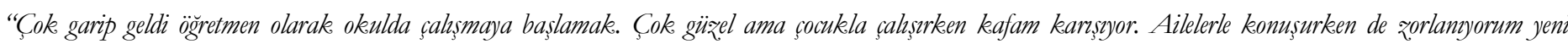
ögretmen olduğum icin sanki güvenmiyorlar gibi bissedivorum bazen. Okuldakilere alsstım ama tabii ögretim disında da isler var. Onlara alssmava calssyorum. Resmi

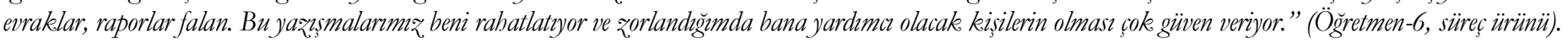

"Illk zamanlar özellikle devlet kurumlarnndaki resmi süreçler, iliskiler, net olmayan görev tanmlarn gibi konular yabano gelebiliyor. Ben uygulamada çalsmaya başladiğm ilk zamanlarda nereden başlayacağım konusunda zorlanyordum. Bu ögrencinin neresinden tutmahyzm, öncelik ne olmal, nasıl birçok eksiğgini

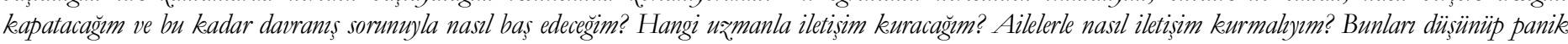
olurdum. Etrafimdaki daha deneyimli ögretmenlere bir seyler sormak, onlarm sinflarnnda gözlemler yapmak ve ayrnca bunaldrğgmda onlarla konusmak çok iyi geliyordu. Aynca, konuyla iligli okumak ve seminerlere katılmak beni cok güclendirmiști. Sürece uyum sağlamamu kolaylaștırmıșt. Ancak keșke daha kolay uyum sağlamam için sunulmus profesyonel destekler olsayd, her şey daba kolay ve çabuk olurdu." (Mentor-1, süreç ürünï). 
Güleç Aslan, Y., \& Sola Özgüç, C. (2017). Öğretmenliğin ilk ylllarında otizm spektrum bozukluk tanllı öğrencilerle çalışan özel eğitim öğretmenlerine uygulanan mentorluk programının ikinci yllına bakıs. Journal of Human Sciences, 14(4), 3548-3570. doi:10.14687/ihs.v14i4.4930

\section{Tablo-2-devam: Çevrimiçi mentorluk programının içeriği}

Konular

Oryantasyon

\section{Örnek alıntılar}

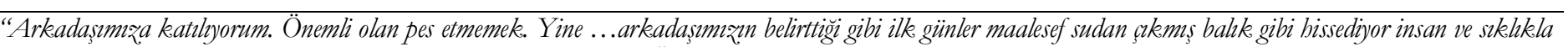
“ee simdi ne yapucam?” sorusunu sorarken bulabiliyor kendisini‡. Öncelikle, ögrenciyi ve ailesini tanmaya, onlarla iyi bir iletisim kurmaya odaklanmak, diğer meslektaslardan mesleki ve kişisel olarak zorlamilan konularda destek istemek, okumak, araștirmak ve okul disında keyifli bir seyler yaparak kendimizi rabatlatmak ise yarayabiliyor. Kendimize zaman ayırmak önemli. Yorucu bir is yapıyoruz. Bir de hem kendinize bem de ögrenciye zaman vermeniz lazım." (Mentor1, süreçürünï).

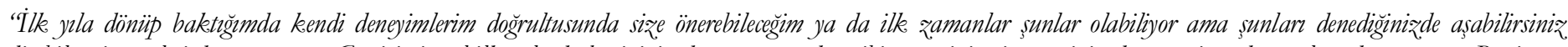

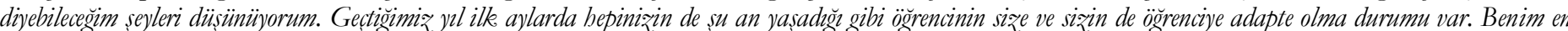

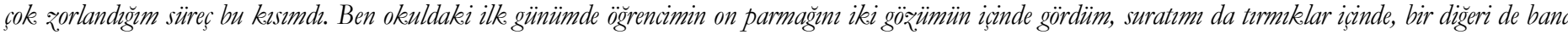

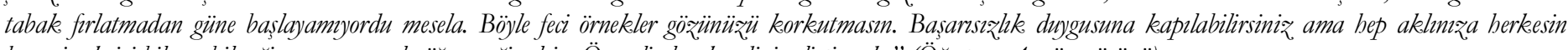
herş̧yi çok iyi bilmeyebileceği, ama zamanla ögreneceği gelsin. Önemli olan kendini gelistirmek.” (Öğretmen-4, sürec ürünü).

"Okuldaki diğer ögretmenlerle iyi iliskiller gelistirmeye gayret etmek okula uyumu kolaylaștiryor, özellikle deneyimli ögretmenlerden fikir almak hem psikolojik hem de mesleki olarak benim okula alıs̆mam sağladı." (Ögretmen-4, süreç ürünü).

"Ailelerle sürekli iletişim halinde olmak işleri kolaylaştrryor. Çocuk bakkenda onlardan alnan bilgiler çocuğa daba kolay uyum sağlamam sağlad. Aynrca, siz̨in

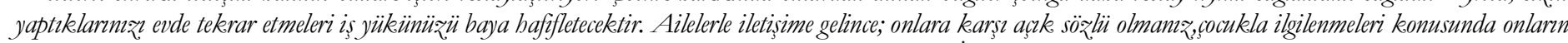
katıliminn her zaman çok önemli olduğunu hissettirmeniz lazım.Böylece ailelerle sorun yașanmiyor. Illk baslarda zorlansam da bu ișten en çok baz aldiğm durumlar

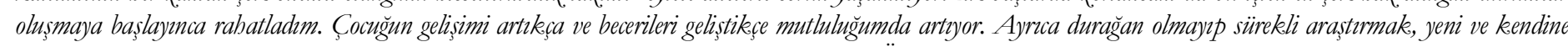
özgü yöntemler bulmak insam bu alanda çalsısırken mutlu eden etkenlerin başında geliyor.” (Öğretmen-5, süreç ürünü).

"Okulun ilk günlerinde biraz zorlandim. Özellikle simfa girdiğimde șașirdim ve nereden başlamam gerektig̈ini bilemedim. Ama yavas yavas alsılyorum. Siz̨lerin

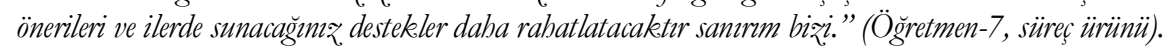


Güleç Aslan, Y., \& Sola Özgüç, C. (2017). Öğretmenliğin ilk yıllarında otizm spektrum bozukluk tanılı öğrencilerle çalışan özel eğitim öğretmenlerine uygulanan mentorluk programının ikinci yılına bakış. Journal of Human Sciences, 14(4), 3548-3570. doi:10.14687/ihs.v14i4.4930

\section{Tablo-2-devam: Çevrimiçi mentorluk programının içeriği}

\section{Konular}

\section{Örnek alıntılar}

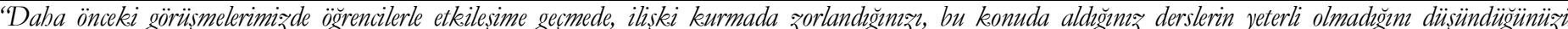

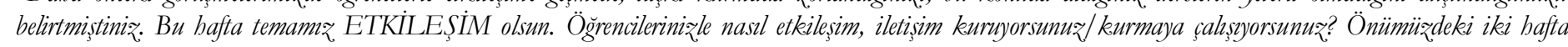
gündemimiz, bu konu olsun.” (Mentor-2, süreç ürünü).

"Kesinlikle süper bir tema $\odot:$ "(Öğretmen-4, süreç ürünü).

"Öğrenci ile etkileşim konusunda, ögrencilerle ilk önce sevdiğgi bir konu veya oyun üzerinden başlyyorum. Oyun oynuyorum. Şarkılar söylïyorum. (Öğgretmen-4, süreç ürünü).

“Otižmi olan ögrencilerle iletişim kurmak zor. Genel olarak, zorlanyyorum belki yeni olduğum içindir.” (Öğgretmen-6, süreç ürünü).

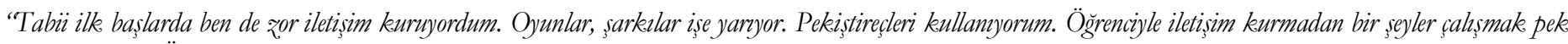
etkili olmuyor."(Öğretmen-1, sürec ürünü).

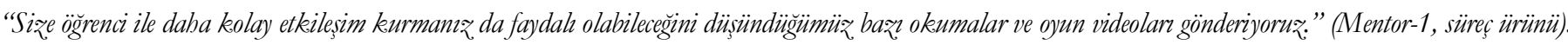

"Hocam makaleyi okudum. Yyazdıklarmı̨ı ve verdiğiniz ekteki videoyu seyrettim çok açklayzc olmuș." (Öğretmen-4, süreç ürünü).

"Bu konu benim açudan çok önemli hocam, iletişime gę̧me noktasinda uyguladı̆ğm şeyler olsa da yeterince başarll olamyorum galiba..."(Öğretmen-5, süreç ürünü).

"Gönderdiğim makale sizlere cok yardımo olacak. Ayrnca, PECS ilgili bilgileri takip edebilirsiniæ. Tablet uygulamalar hakekında da bilgi yazacağrz size."(Mentor1, süreçürünü).

"Alternative and augmentative communication system- $A A C$ " seklinde anabtar kelimeler ile girince, internette cok, farla uygulama alk.yor. Forumlarda en cok Alternatif ve Destekleyici eleştirilen nokta da tam sürüm yüklenmediğinde çok verimli sonuçlar alnmadiğ. Bence bu anabtar kelimeler ile inceleyip bakabilirsin. Tavsiyem çok. fazla uygulama İletişim Sistemleri (ADİS) arasinda kalmamam. Son bir öneri. Say Hi" uygulaması bize fotoğraf çekip seslendirme imkan veriyor. Bu da faydali olabilir." (Mentor-2, süreç ürünü).

"Teşekekürler hocam. Önerdiğini tablet uygulamalar çok anlaşıllr ve işime yaryor."(Öğretmen-5, süreç ürünü).

“Bu konudaki bilgilerim yeterli değil, makale ya da neler yaptı̆̆nnza ilişkin notlar gönderi misiniz̨?’(Öğretmen-3, süreç ürünü).

"Öğretmenlerin bu konuda desteğe çok ibtiyac var gibi görünüyor. Ashnda bu konuya lisans döneminde derslerde fazlaca yer vermek lazım. Ayruca, bu gruba daba fąla okuma vb. gönderebiliriz:” (Mentor-1, arastrrmacn günlï̈̈̈i) 
Güleç Aslan, Y., \& Sola Özgüç, C. (2017). Öğretmenliğin ilk ylllarında otizm spektrum bozukluk tanılı öğrencilerle çalşan özel eğitim öğretmenlerine uygulanan mentorluk programının ikinci yllina bakıs. Journal of Human Sciences, 14(4), 3548-3570. doi:10.14687/ihs.v14i4.4930

\section{Tablo-2-devam: Çevrimiçi mentorluk programının içeriği}

Konular

Konular

Örnek alıntılar

\section{Ornek alıntılar}

"Merhaba hocam, "Otižmli Çocuklara Konusma Becerilerinin Öğretimi: Replikli Ögretim” adh bir makale okudum. Sižlere de önermek istedim. Ayrnca, konusma becerilerini arturabileceğimiz bașka yöntemler hakeknda bilgi verebilir misiniz?.”(Öğretmen-5, süreçürünü).

"Ögretmenlerin en zorlandıklan konulardan biri” (Mentor-2, arastrmac günlüğ̈i).

"Fursat ögretimi gibi yöntemleri ifade edici dil becerileri kazanderma da kullanabilirsin. Bu konuda yaz̨l materyalleri ve video örneklerini gönderiyorum."(Mentor-2, süreşürünü).

Ifade Edici Dil

"Tiletişim becerilerini geliștirme konusuna gelince aslinda derslerde erken yoğun davranıssal eğitim, OÇIDEP programlarm görmüstük. Oradaki gibi taklit, eșleme gibi temel programlardan başlyorum. Bazen zorlanyorum, zorlandiklarm siz̨lere sorarm. Ama birkaç ögrencide işe yaradiğm gördüm.”(Öğretmen-5, süreç ürünü).

"Ashnda bu konuda Türkçe kaynaklar ve takip edebilecekleri kaynaklar var. Derslerde de üzerinde sıleça duruluyor. Ancak uygulama aşamasmda zorlanyyorlar. Daha faそla uygulamaya dönük. bilgi kaynaklar sunulmal, lisanslarda uygulama ortamlar yaratılmah.” (Mentor-1, araştırmac günlügüi).

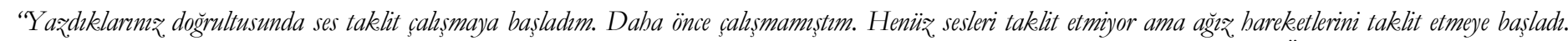
Babsettiğiniz gibi aslinda taklit becerilerini tamamlamadan çocuktan konusmaya başlamasım beklemek pek anlamh gelmiyor simdi.” (Öğretmen-3, süreç ürünï).

"Fursat ögretimini kullanmaya bassladım. Verdiğiniz geribildirimler ve okumalar ișime yaryor.” (Öğretmen-6, sürec ürünü).

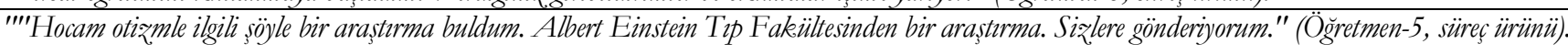

"Merhaba, bu konuda herbangi bir bilgim yok ama eğer başka çalısmalar bulursak gönderelim birbirimiz:" (Mentor-1, süreçürünü).

"Ekete çeşitli konularda makaleler var. Okuyabilirsiniz: Sorularmı olursa konusalim grupta." (Mentor-2 süreçürünler).

"Öğretmenlerin özellikle uygulamayla iliskili araștırmalan okumalar, aynca kuramsal bilgilerini arttracak bilimsel çalsmalarn ve kitaplarn okumalarn onlarm motivasyonunu artturyor. Bilgilerini geliștiriyor. Gruptaki ögretmenler bu konuda çok heveshiler.” (Mentor-1, arasttrmac günlï̈̈̈i).

Yazılı materyal paylaşımı

"Hocam ekte siz̨e bir dosya gönderiyorum.Dosyada otizmli bireyler için diyet listesi var.Siz̨ce bunlar ailelere tavsiye olarak vermemiz cocuklar için fayda sağlar m??Y a da buna yönelik önerileriniz var m??” (Öğretmen-5, süreç ürünü).

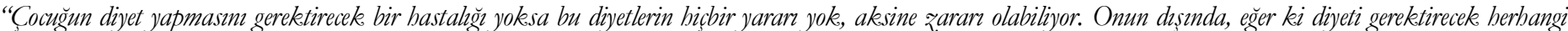

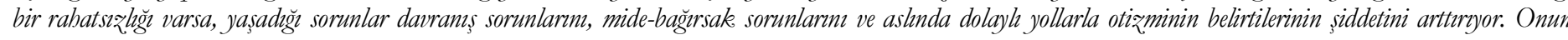
için bu tür diyetler yapılyyor. Ancak, bu konuda užman bir doktorun kontrolü ve önerileri doğrultusunda diyet konusuna karar veriliyor. Dolayısiyla, diyet konusunu

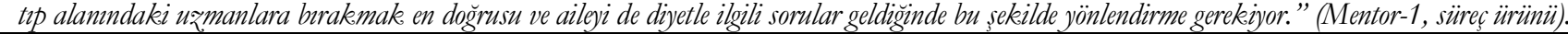


Güleç Aslan, Y., \& Sola Özgüç, C. (2017). Öğretmenliğin ilk ylllarında otizm spektrum bozukluk tanılı öğrencilerle çalşan özel eğitim öğretmenlerine uygulanan mentorluk programının ikinci yllina bakıs. Journal of Human Sciences, 14(4), 3548-3570. doi:10.14687/ihs.v14i4.4930

\section{Tablo-2-devam: Çevrimiçi mentorluk programının içeriği}

\section{Konular}

\section{Örnek alıntılar}

“Bir sonraki tema otizmli cocuklarda ki takıntıl davramıslarla bașa g̣kma olsun mu?’(Öğretmen-5, sürec ürünü).

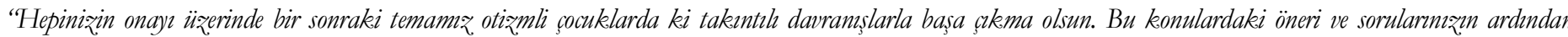
sizllere bazı metinler gönderecę̆iz:"."(Mentor-1, süreç ürünü).

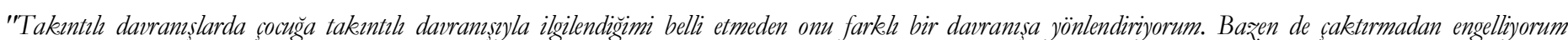

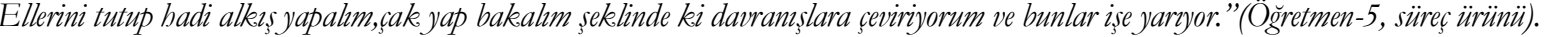

"Merbaba, yaptıklarn uygun görünüyor, işe yarayan yollar"."(Mentor-1, süreç ürünü).

"Ben de ekte bir belge gönderiyorum. Belgeyi ingiližce bir kaynaktan çevirdim. Basit, yaln bilgiler olduğunu düsündüm.".”(Mentor-2, süreç ürünü).

Takıntılı davranışlar

"Takemtıl dauranıslarda derslerde ögrendiklerimizi uyguluyoruz ama ilk derslerde çok zordu. Halen zor ama simdi burada yazılanlardan da faydalanyoruz:"(Öğgetmen-7, süreç ürünü).

"Öğretmenlerin en zorlandiklar konulardan bir tanesi de takentıl dawramşlar. Kafalar karsşyor ve bangi yöntemleri kullanacaklarm tam bilemiyorlar. Umarmm biraz da olsa faydah oluru:" (Mentor-1, araștrmacr günlï̈̈̈i).

"Ekolali ile ilgili nasıl bir yol įleyebilirim”. (Öğretmen-7, süreç ürünü).

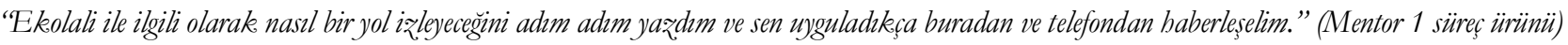

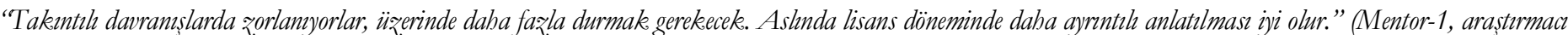
günlï̈üi). 
Güleç Aslan, Y., \& Sola Özgüç, C. (2017). Öğretmenliğin ilk ylllarında otizm spektrum bozukluk tanılı öğrencilerle çalşan özel eğitim öğretmenlerine uygulanan mentorluk programının ikinci yllina bakıs. Journal of Human Sciences, 14(4), 3548-3570. doi:10.14687/ihs.v14i4.4930

\section{Tablo-2-devam: Çevrimiçi mentorluk programının içeriği}

\section{Konular}

\section{Örnek alıntılar}

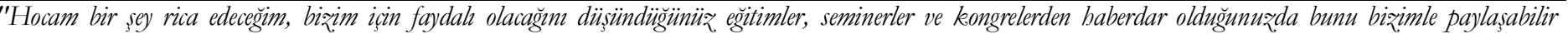

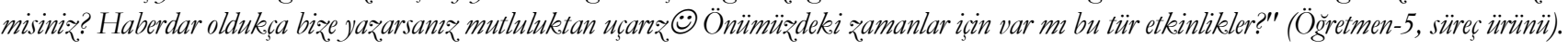

"Tabii ki çok güzel bir içerik bu."."(Mentor-1, süreç ürünü).

Kurs, Seminer ve Kongre “Arkadaşlar ben İstanbul'da baž seminerleri belirledim, sį̨lere de gönderiyorum.” (Öğretmen-4, süreç ürünü).

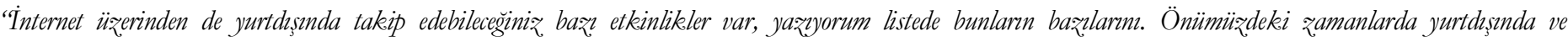
Türkiye'de olacak kongreler var. Bunlar size liste olarak yazacağzm."(Mentor-1, süreç ürünü).

"Özellikle her ynl düzenli olarak yapulan öz̧el eğitim kongresi, ABAI gibi kongreleri takip edebilirsiniz. Bunlar kongrelerin yer aldh̆g siteler var, arasira bakabilirsiniz:" (Mentor-1, süres ürünü).

"Ögretmenlere bu konularda bilgilendirme yapmak onlarn kendini gelistirmesi için oldukşa önemli”. (Mentor-1, arastırmacu günlïgüi).

" Hocam OÇIDEP'i kendim tek başina uyguluyorum belirtildiği gibi bir ekiple götürmüyorum süreci ve ögrenciyle bu şekilde günde ikei saat olmak üzere haftada 8 saat çalsısyorum siz̨ce doğru yapıyor muyum?"(Ögretmen-5, süreç ürünü).

"Evet belirttiğ çocuklarla uygulamalarn doğru, ben de aynısın yapar ve mümkünse evde de çalşslmasın să̆lardım."(Öğretmen-5, süreç ürünü).

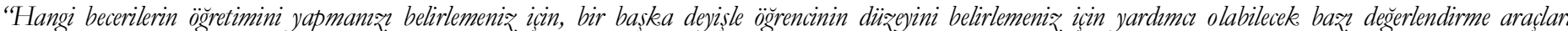
gönderiyorum."(Mentor-1, süreç ürünü).

“Cocukta benüz eşleme becerisi yok. Ayrk denemelerle ögretim kullanmak konusundaki görü̈leriniz neler?” (Öğretmen-4, süreçürünü).

Öğretim yöntemleri

“Öğretim yöntemleri ile ilgili olarak ashnda pek çok konuyu biliyorlar. Uygulamada kafalarna takılan konular var.” (Mentor-1, araștırmaci günlï̈g̈̈i).

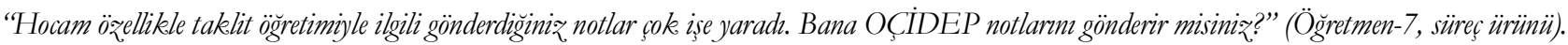

“Sizlere etkinlik çizelgeleri ve doğal ögretim yöntemleri hakkenda kaynak kitap adlan ve video örnekler gönderiyorum.” (Mentor-1, süreçürünü).

“Acaba ailelere öğretim yöntemleri hakkeında kısa bilgi verebileceğimiz bir broşür hažrlamak nasıl olur?”. (Öğrenmen 2-süreç ürünü).

"Aslanda broșür güzel fikir. Özellikle temel ve sık kullanulan yöntemleri akuc bir dille anlatan broșürler olabilir. Bireysel ya da grup olarak. bir eğitim verilip ardindan bu brosï̈ler dağztılabilir. "(Mentor-1, süreş ürünü). 
Güleç Aslan, Y., \& Sola Özgüç, C. (2017). Öğretmenliğin ilk yıllarında otizm spektrum bozukluk tanılı öğrencilerle çalışan özel eğitim öğretmenlerine uygulanan mentorluk programının ikinci yllına bakış. Journal of Human Sciences, 14(4), 3548-3570. doi:10.14687/ihs.v14i4.4930

\section{Tema 3: Çevrimiçi mentorluk programının güçlü ve eksik yönleri}

Bulgular öğretmenlerin üç tanesinin (Ö-2, Ö-3, Ö-7) programın çevrimiçi olmasından memnun olduğunu göstermektedir. Örneğin, öğretmen-2 "kesinlikle çevrimiçi olması bence daha pratik ve kolay", öğretmen-3 ise "çevrimiçi olması vakit anlaminda da çok pratik oldu. Farkh şehirlerde ögretmenlere ulassmak için iyi bir yol" ifadeleri ile süreç ürünlerinde görüşünü belirtmiştir. Öğretmenlerin üçü (Ö-4, Ö-5, Ö-6) program boyunca görüşülen konuların kendi ihtiyaçlarından ve sorunlarından yola çıkılarak belirlenmesinin, yazılı ve görsel materyal paylaşımı yapılmasının, kuramsal bilginin yanı sıra bu bilgileri nasıl uygulayacaklarına ilişkin de yol gösterilmesinin programdan faydalanmalarını sağlayan önemli unsurlar olduğunu belirtmişlerdir. Bu bulgulara örnek ifadeler şöyledir: 'Program boyunca neye ibtiyacumı, varsa o yönde paylaşmlar yapuld, uygulama örneklerini seyredebileceğimiz videolar paylaşıldı." (Öğretmen-4, süreç ürünü ve görüş formu), "bize ibtiyaçlarmmı̨n sorulması ve konular belirlenirken bizlere damısılması çok önemliydi. Çünkü bize yönelik bir programda konularn biz̨e sorulmadan belirlenmesi çok anlaml olmazdr." (Öğretmen-5, süreç ürünü ve değerlendirme formu), "sadece kuramsal yönde değil uygulamalar nasul yürüteceğimiz konusunda da yol gösterici paylasımlarda bulunuldu. Bu faydalı oldu benim için.” (Öğretmen-6, süreç ürünü). Ayrıca, iki öğretmen (Ö-4, Ö-5) programın mesleki konular dışında kişisel konuları (motivasyon, kayg1, vb.) kapsamasının da programın güçlü yönü olduğunu ifade etmişlerdir. Mentorluk programı değerlendirme formunda "aslinda ben en çok moralimin bozulduğu ve motivasyonum bozulduğu anlarda bu programdan çok faydalandım, bu yönünü çok sevdim" (öğretmen-4) ve "bir de bize sadece mesleki konularda değil, kaygzlandiğrmızda ya da motivasyonumuz düstiügünde de destek sunulmasindan çok memnun kaldım” (öğretmen-5) gibi ifadeler göze çarpmaktadır.

Sadece bazı öğretmenler $(N=4)$ çevrimiçi sunumun yanı sıra yüz yüze görüşmelerinde yapılmasının bu tür programları daha faydalı hale getirebileceğine ilişkin görüşler bildirmişlerdir. Öğretmenler bu konudaki görüşlerini şu tür ifadelerle bildirmişlerdir. "Farklh şehirlerde yaşanmasindan

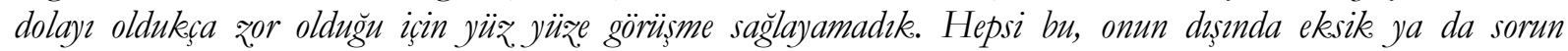
diyebileceğim bir durum yok. Belki kendi videolarmız falan yükleyip birbirimize geribildirim verebilirdik." (Öğretmen-4, süreç ürünü), "bu tür programlara imkan dabilinde oldukça yür yüre görü̈sme eklenerek, tüm bu

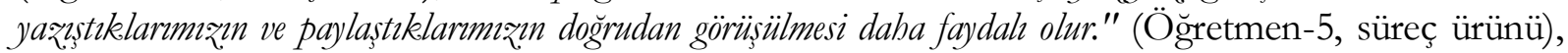

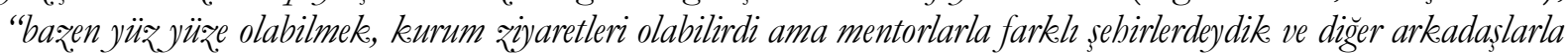

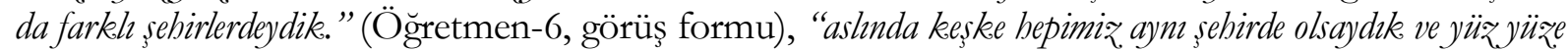
görü̈meler olsaydr daha etkili olabilirdi. Ya da arada yüz yüze olup, hem de böyle internet arachlğgyla da olabilirdi." (Öğretmen-1, görüss formu). Mentorların günlüklerinde de "programa görüntülü konuşma gibi unsurlar, video konferanslar ekleyebilirdik”” şeklinde ifadeler görülmektedir (Mentor-1, araştırmacı günlüğü).

\section{Tartışma}

$\mathrm{Bu}$ araştırmada mesleğinin ilk yıllarını OSB alanında çalışan Z.E.Ö. bölümü mezunu öğretmenlere yönelik geliştirilmiş bir çevrimiçi mentorluk programının ikinci ylı nitel olarak incelenmiştir. Bu doğrultuda, bu çevrimiçi mentorluk programının içeriği incelenip, programın faydaları, eksik ve güçlü yönleri katılımcı görüşleri bağlamında değerlendirilmiştir.

Araştırmanın çevrimiçi mentorluk programının içeriği teması bağlamındaki bulgular, programın yürütülme planı doğrultusunda katılımcıların ihtiyaçları temelinde belirlenen konuların program içeriğinde ele alındığını göstermektedir. Bu konular; oryantasyon, öğrenciyle etkileşim, Alternatif ve Destekleyici İletişim Sistemleri (ADİS), ifade edici dil, takıntılı davranışlar, kurs, seminer ve kongre, öğretim yöntemleri ve yazılı materyal paylaşımıdır. Mentorluk programı boyunca araştırma katılımcılara bu konulara yönelik destek sunulmuştur. Bulgular alanyazın bulgularıyla tutarlılık göstermektedir. Alanyazında da mesleğinin ilk yıllarında OSB alanında çalışmaya başlayan yeni öğretmenlerin desteğe ihtiyaç duydukları konuların, bu araştırma katılımcının belirttikleri konularla benzer olduğu ve mentorluk programlarının içeriklerinin bu ihtiyaçlar doğrultusunda planlandığ1 görülmektedir. (Barnhill ve diğ., 2011; Boyer ve Lee, 2001; Ergenekon, 2005, 2009; Güleç-Aslan ve Sola-Özgüç, 2017; Litton ve diğ., 2017; Marder ve deBettencourt, 2012; Sebald ve Rude, 2015; Simpson, 2004). 
Güleç Aslan, Y., \& Sola Özgüç, C. (2017). Öğretmenliğin ilk yıllarında otizm spektrum bozukluk tanılı öğrencilerle çalışan özel eğitim öğretmenlerine uygulanan mentorluk programının ikinci yllına bakış. Journal of Human Sciences, 14(4), 3548-3570. doi:10.14687/jhs.v14i4.4930

Diğer bir bulgu, çevrimiçi mentorluk programının faydaları teması doğrultusunda ele alınmıştır. Araştırmanın katılımcısı tüm öğretmenler, bu programın, mesleki yeterliliklerin gelişiminde katkı sağladığını, beş öğretmen iş yaşamına uyumlarını ve bu yeni durumun getirdiği psikolojik sıkıntılarla (kayg1, vb.) baş etmelerini kolaylaştırdığını belirtmişlerdir. Dört öğretmen ise, bu faydaların yanı sıra, bu program sayesinde mesleklerini daha çok sevmeye ve otizm alanında çalışmaktan daha fazla keyif almaya başladıklarını ifade etmişlerdir. Bir başka deyişle, bu çevrimiçi mentorluk programının araştırmanın katılımcısı öğretmenlere mesleki ve kişisel yönlerden fayda getirdiği söylenebilir. Alanyazında da belirtildiği üzere, özellikle öğretmenlerin sorun ve ihtiyaçları temelinde hazırlanan mentorluk programları, işe yeni başlayan tüm öğretmenler ve özellikle de OSB alanında çalışan öğretmenler için fayda sağlamaktadır. Öğretmenlerin ihtiyaçları temelinde planlanıp yürütülen mentorluk programları yeni öğretmenlerin işe uyumlarını kolaylaştırmakta, bilgi ve beceri düzeylerini arttırmakta ve mesleki doyumlarını arttırmaktadır (Barnhill ve diğ., 2011; Billingsley ve diğ., 2011; Marder ve deBettencourt, 2012; Simpson, 2004). Böylece bu öğretmenlerin ilk y1lların1 başarılı bir şekilde geçirebilmeleri söz konusu olmaktadır (Barnhill ve diğ., 2011; Billingsley ve diğ., 2011; Gentry, 2016; Israel ve diğ., 2014; Jones ve diğ., 2015; Litton ve diğ., 2017; Manzar-Abbass ve diğ., 2017;Marder ve deBettencourt, 2012; Parker-Katz ve Hughes, 2008).

Çevrimiçi mentorluk programının güçlü ve eksik yönleri teması doğrultusundaki bulgular ise, üç öğretmenin programın çevrimiçi olmasını programın güçlü yönü olarak bildirdiğini göstermektedir. Alanyazın bulguları da, teknolojinin eğitim alanında etkin ve etkili kullanımının yaygınlaşmasıyla, özellikle de program katılımcıları farklı yerleşim yerlerindeyse çevrimiçi mentorluk programlarının, pratik ve etkili bir şekilde yürütülmesini sağlayabildiğini vurgulamaktadır (Kuzu ve diğ., 2012; Ludlow ve diğ., 2007; O’Neill, Weiler ve Sha, 2005; Marder ve deBettencourt, 2012; Simpson ve diğ., 2016). Ayrıca, program boyunca görüşülen konuların katılımcıların ihtiyaçları temelinde yürütülmesi, yazılı ve görsel materyal paylaşımı yapılması, kuramsal bilgileri öğrencilerinde uygulamalarına yol gösterici olması üç öğretmen tarafindan ve programın mesleki konular dışındaki kişisel konuları (motivasyon, kayg1, vb.) kapsaması iki öğretmen tarafından programın güçlü yönleri olarak belirtilmiştir. Bu bulgular alanyazınla tutarlılık göstermektedir. Benzer çalışmalarda da etkili mentorluk programlarının içeriğinin öğretmenlerin bildirdikleri ihtiyaçlarından oluşturulması, kuram ve uygulama boyutlarının olması, mesleki yeterliliklere yönelik desteğin yanı sıra sosyal ve psikolojik desteği içermesi ve farklı ögretim yöntemleri ve materyallerle eğitimlerin sunulması gibi unsurlara sahip olması gerektiği vurgulanmaktadır (Babione ve Shea, 2005; Billingsley, ve diğ., 2011; Jones ve diğ., 2015; Parker-Katz ve Hughes, 2008; Sebald ve Rude, 2015). Dört öğretmen ise, her ne kadar koşulların (katılımcıların farklı yerleşim yerlerinde olması, vb.) mentorluk programının çevrimiçi yürütülmesini gerektirmesine rağmen, çevrimiçi sunumun yanı sıra yüz yüze görüşmelerin yapılmasının programı daha faydalı hale getirebileceğini bildirmişlerdir. Alanyazında, çevrimiçi mentorluk sunumu dışında, mentorun sınıf içinde ve/veya sınıf dışında öğretmene destek sunmasının da söz konusu olduğu belirtilmektedir (Billingsley ve diğ., 2011; Gentry, 2016; Kuzu ve diğ., 2012; Sebald, ve Rude, 2015). Ancak, mentorluk programlarının faydalı olmasında, programın nasıl sunulduğundan ziyade, programın öğretmenlerin ihtiyaçları ve sorunları temelinde hazırlanmasının, mentor ile öğretmenin mesleki ilgi ve alanlarının benzer olmasının, programın çeşitli özelliklere sahip olmasının (kuramsal bilginin yanı sıra uygulamaya yönelik nitelikler taşıması, vb.), mentorun çeşitli mesleki yeterliklerinin ve kişilik özelliklerinin (empati kurabilmesi, dinleme becerilerinin niteliği, vb.) bulunmasının önemli olduğu belirtilmektedir (Amos, 2005; Babione ve Shea, 2005; Jones ve diğ., 2015; Smith ve Israel, 2010; Whitaker, 2000). Ayrıca, sunum türlerinin faydalarının birbirine benzer olduğu (Billingsley ve diğ., 2011, Dempsey, Arthur-Kelly, ve Carty, 2009); ancak özellikle farklı şehirlerde yaşayan mentor ve öğretmenler söz konusu olduğunda çevrimiçi mentorluk programlarının etkili olduğu bildirilmektedir (Gentry, 2016; Marder ve deBettencourt, 2012; O’Neill, Weiler ve Sha, 2005).

$\mathrm{Bu}$ araştırmanın, meslekte yeni olan öğretmenlerin, ilk yıllarının başarılı ve olumlu geçmesi amacıyla uygulanacak çevrimiçi mentorluk programlarının planlanması ve yürütülmesi sürecine 1şık 
Güleç Aslan, Y., \& Sola Özgüç, C. (2017). Öğretmenliğin ilk yıllarında otizm spektrum bozukluk tanılı öğrencilerle çalışan özel eğitim öğretmenlerine uygulanan mentorluk programının ikinci yllına bakış. Journal of Human Sciences, 14(4), 3548-3570. doi:10.14687/jhs.v14i4.4930

tutabileceği düşünülmektedir. Ayrıca, konuyla ilgili sınırlı alanyazına katkıda bulunması beklenmektedir. Özellikle de, mentorluk programının araştırma katılımcılarının görüşlerine ve yaşantılarına dayalı olarak hazırlanması ve araştırmanın katılımcıların bakış açısı temelinde programın değerlendirildiği bir nitel araştırma olması araştırmanın güçlü yanları arasındadır. Ancak, araştırmanın bazı sınırlılıkları bulunmaktadır. Verilerin toplama sürecinde görüşme gibi diğer nitel veri toplama yöntemlerinden ve nicel değerlendirme yöntemlerinden faydalanılabilirdi. Araştırma, bir önceki araştırmanın (Güleç-Aslan ve Sola-Özgüç, 2017) sonuçları temelinde yürütülen bir devam çalışması olduğundan sadece bir üniversitenin mezunlarıyla sınırlı tutulmuş olsa da, farklı üniversitelerin mezunlarının çalışmaya alınamaması bir sınırlılık olarak düşünülebilir. Ayrıca, çevrimiçi mentorluk programı süresince üç öğretmenin (Ö-1, Ö-3, Ö-7) dördüncü aydan sonra paylaşımları azalmıştır. Öğretmenler bu durumun nedenleri olarak; zamanlarının azlığını, yazılanları takip ettiklerini ve görüşülenleri uyguladıklarını ancak paylaşacakları çok fazla konu olmadığını, internet erişimlerinde sorunlar yaşadıklarını belirtmişlerdir. Ancak, bu durumun olası nedenleri bu çalışma kapsamında sistematik olarak araştırılmamıştır. Ayrıca, bu üç öğretmenden görüş formu geri dönmemiştir. Programin sonlanmasından sonra okullardaki sene sonu etkinliklerinin yoğunluğu ve daha sonra yaz tatilinin devreye girmesi bu durumun nedenleri olabilir ancak bu konu da araştırma kapsamında sistematik olarak araştırılmamıştır. Bunlar araştırmanın sınırlılıkları olarak ele alınabilir.

Araştırmanın bulguları doğrultusunda uygulama alanına ilişkin öneriler şöyledir: (a) İlgili kurum ve kuruluşlarca (bakanlıklar, üniversiteler, vb.) OSB olan bireylerle mesleklerinin ilk yıllarında çalışan öğretmenlere yönelik olarak mentorluk programları geliştirilebilir. Özellikle de farklı yerleşim yerlerinde yaşayan öğretmenler ve zaman sinırlllı̆̆1 söz konusu ise, çevrimiçi mentorluk programları hazırlanabilir, (b) ilgili kurum ve kuruluşlarca (bakanlıklar, üniversiteler, vb.) mentorluk programı dışında işe uyum programları düzenlenebilir, (c) özel eğitim öğretmen adaylarına lisans dönemlerinde OSB ağırlıklı ders ve seminer imkanları arttırılabilir. OSB tanılı bireylerle bir arada olmalarına firsat tanıyacak düzenlemelere (gönüllü çalışmalar, okul ziyaretleri, vb.) ağırlık verilebilir, (d) öğretmenlerin ve öğretmen adaylarının var olan adaylık eğitimleri ve staj uygulamaları mentorluk programı unsurları bağlamında yeniden düzenlenebilir.

Bulgular doğrultusunda ileri araştırmalara yönelik öneriler ise şu şekilde sıralanabilir: (a) farklı katılımcıların yer aldığı nitel ve nicel araştırmalar yürütülebilir, (b) farklı mentorluk modellerine dayalı karşılaştırmalı araştırmalar yürütülebilir, (c) farklı veri toplama yöntemlerine dayalı nitel araştırmalar yürütülebilir, (d) mentorluk programlarının etkililiklerine yönelik değişkenlerin incelendiği nicel araştırmalar yürütülebilir, (e) mentorluk programlarına katılan öğretmenlerin programa katılım düzeylerini etkileyen değişkenlerin incelendiği araştırmalar yapılabilir.

\section{Yazar Notları}

Yazarlar, katılımcı öğretmenlere ve geçerlik çalışmalarına katılan uzmanlara teşekkrülerini sunarlar. Bu çalışma, "Mentoring Novice Teachers of Students with Autism: A Case Study" başlıklı poster bildiri olarak Uluslararası Otizm Konferansinda (ULOK) (International Conference for Autism-INCA) sunulmuştur.

\section{Kaynakça}

Alexander, L. J., Ayres, M. K. \& Smith, A. K. (2015). Training teachers in evidence-based practice for individuals with autism spectrum disorder: A review of the literature. Teacher Education and Special Education, 38 (1), 13-27.

American Psychiatric Association, Diagnostic and Statistical Manual of Mental Disorders (DSM-5) (2013). American Psychiatric Publishing, USA.

Babione, C. \& Shea, C. (2005): Special education mentoring within the context of rural schools. Rural Special Education Quarterly, 24 (2), 3-10. 
Güleç Aslan, Y., \& Sola Özgüç, C. (2017). Öğretmenliğin ilk yıllarında otizm spektrum bozukluk tanılı öğrencilerle çalışan özel eğitim öğretmenlerine uygulanan mentorluk programının ikinci yllına bakış. Journal of Human Sciences, 14(4), 3548-3570. doi:10.14687/jhs.v14i4.4930

Barnhill, G. P., Polloway, E. A. \& Sumutka, B. M. (2011). A survey of personel preparation practices in autism spectrum disorders. Focus on Autism and Other Developmental Disabilities, 26 (2), 75-86.

Billingsley, B. S. \& Cross, L. H. (1992). Predictors of commitment, job satisfaction, and intent to stay in teaching: A comparison of general and special educators. The Journal of Special Education, 25 (4), 453-471.

Billingsley, B. S. (2004). Special education teacher retention and attrition: A critical analysis of the research literature. The Journal of Special Education, 38 (1), 39-55.

Billingsley, B., Israel, M. \& Smith, S. (2011). Supporting new special education teachers. Teaching Exceptional Children, 43 (5), 20-29.

Boyer, L. \& Lee, C. (2001). Converting challenge to success: Supporting a new teacher ofstudents with autism. The Journal of Special Education, 35 (2), 75-83.

Brantlinger, E., Jimenez, R., Klingner, J., Pugach, M. \& Richardson, V. (2005). Qualitative studies in special education. Exceptional Children, 71 (2), 195-207.

Creswell, W. J. (2005). Educational research. Upper Saddle River, N.J.: Pearson.

Crisp, G. \& Cruz, I. (2009). Mentoring college students: A critical review of the literature between 1990 and 2007. Research in Higher Education. 50 (6), 525-622.

Dempsey, I., Arthur-Kelly, M. \& Carty, B. (2009). Mentoring early career special education teacher. Australian Journal of Education, 59 (3), 294-305.

DeWert, M. H., Babinski, L. M. \& Jones, B. D. (2003). Safe passages: Providing online support to beginning teachers. Journal of Teacher Education, 54 (4), 311-320.

Eikeseth, S. (2010). Examination of qualifications required of an EIBI Professional, European Journal of Behavior Analysis, 2 (11), 239-246.

Elrod, G. F., Coleman, A. M., Shumpert, K. D. \& Medley, M. B. (2005). The use of problembased learning in rural special education preservice training programs. Rural Special Education Quarterly, 24 (2), 28-32.

Ergenekon, Y. (2005). İse yeni baslayan zihin özürlüler öğretmenlerinin mesleksel sorunlarmmn belirlenmesi ve bu sorunlar gidermeye yönelik önerilerin gelistirilmesi (No.1622). Eskişehir: Anadolu Üniversitesi Yayınları.

Ergenekon, Y. (2009). Özel eğitim öğretmenlerine mesleklerinin ilk yllında sağlanan destekler. Ankara Üniversitesi Eğitim Bilimleri Fakültesi Dergisi, 42 (1), 215-239

Ergül, C., Baydık, B. \& Demir, Ş. (2013). Özel eğitim öğretmen adaylarının ve öğretmenlerinin zihin engelliler öğretmenliği lisans programı yeterliklerine ilişkin görüşleri. Kuram ve Uygulamada Eğitim Bilimleri, 13 (1), 499-522.

Gentry, R. (2016). The content of beginning special educators' conversations with their electronic mentors. Journal of International Special Needs Education, 19 (1), 34-45.

Güleç-Aslan, Y. \& Sola-Özgüç, C. (2017). A mentoring program for special education teachers working with students with autism spectrum disorders in their first year of career. Journal of Human Sciences. 14 (1), 528-559.

Güleç-Aslan, Y. (2014). Preservice mental retardation education teachers' perceptions toward autism spectrum disorders field. Kastamonu University Kastamonu Education Journal. 22 (3), 869897.

Hendricks, D. (2011). Special education teachers serving students with autism: A descriptive study of the characteristics and self-reported knowledge and practices employed. Journal of Vocational Rehabilitation, 35, 37-50.

Israel, M., Kamman, L. M., McCray, D. E. \& Sindelar, T. P. (2014). Mentoring in action: The interplay among professional assistance, emotional support, and evaluation. Exceptional Children, 81 (1), (45-63). 
Güleç Aslan, Y., \& Sola Özgüç, C. (2017). Öğretmenliğin ilk yıllarında otizm spektrum bozukluk tanılı öğrencilerle çalışan özel eğitim öğretmenlerine uygulanan mentorluk programının ikinci yllına bakış. Journal of Human Sciences, 14(4), 3548-3570. doi:10.14687/jhs.v14i4.4930

Jones, P., De Kock, J., Charles, D., Jourdan, N., Copeland, S. \& Willis, S. (2015). Insider perspectives on mentoring teachers of students with complex disabilities: A New Zealand Story. Journal of International Special Needs Education, 18 (2), 41-50.

Kırcaali-İftar, G. \& Tekin-İftar, E. (2012). Otizm spektrum bozukluklarına yönelik program örnekleri. E. Tekin (Ed.). Otiæ̌m spektrum bozukluğu olan çocuklar ve eğitimleri içinde, (s. 239-265). Ankara: Vize Yayincilik.

Kodal, B. (2006). Eskişehir ilinde otistik çocuklarla çalışan özel eğitim öğretmenlerinin yaşadıkları sorunlar ve sorunların çözümüne ilişkin görüşleri (Yüksek Lisans Tezi. Anadolu Üniversitesi Eğitim Bilimleri Enstitüsü, Eskişehir).

Koegel, L., Matos-Fredeen, R., Lang, R. \& Koegel, R. (2012). Interventions for children with autism spectrum disorders in inclusive school settings. Cognitive and Behavioral Practice,19 (3), 401-412.

Kuzu, A., Kahraman, M. \& Odabaşı, F. (2012). Mentörlükte yeni bir yaklaşım: E- Mentörlük. Anadolu Üniversitesi Sosyal Bilimler Dergisi, 12(4), 173-183.

Litton, W. F., Anthony, R. R., Coombs-Richardson, R. \& Martinez, R. (2017). Preparation for teachers for students with autism spectrum disorders: A call for quality and quantity. American Journal of Educational Research, 5 (2), 225-230.

Ludlow, B. L., Galyon Keramidas, C. \& Landers, E. J. (2007). Project Stars: Using desktop conferencing to prepare autism specialist at a distance. Rural Special Education Quarterly, 26(4), 27-35.

Major, A. E. (2012). Job design for special education teachers. Current Issues in Education, 15 (2), 1 8.

Manzar-Abbass, S. S., Malik, A. N., Khurshid, A. M. \& Ahmad, S. (2017). Impact of mentoring on teachers' Professional development: Mentees' perceptions. New Horizons, 11 (1), 85-102.

Marder, T. J. \& deBettencourt, L. U. (2012). Using a hybrid model to prepare special educators to teach students identified with ASD. Rural Special Education Quarterly, 31(3), 12-19.

Mehling, H. M. \& Tasse, J. M. (2016). Severity of autism spectrum disorders: current conceptualization, and transition to DSM-5. Journal of Autism and Developmental Disorder, 46: 2000-2016.

O’Neill, D. K., Weiler, M. J. \& Sha, L (2005). Soft-ware support for online mentoringprograms: A research-inspired design. Mentoring \& Tutoring, 13 (1), 109-131.

Özdemir, M. (2010): Nitel veri analizi: Sosyal bilimlerde yöntembilim sorunsalı üzerine bir çalışma, Eskişehir Osmangazi Üniversitesi Sosyal Bilimler Dergisi, 11 (1), 323-343.

Parker-Katz, M. \& Hughes, M. T. (2008). Preparing special education mentors using classroom artifacts as a vehicle for learning about teaching. Teacher Education and Special Education, 31 (4), 268-282.

Scheuermann, B., Webber, J., Boutot, E. A. \& Goodwin, M. (2003). Problems with personel preparation in autism spectrum disorders. Focus on Autism and Other Developmental Disabilities, 18 (3), 197-206.

Sebald, A. M. \& Rude, H. A. (2015). Results of an evaluation study of induction and mentoring for beginning special education teachers: What do they need? Social Welfare: Interdisciplinary Approach, 1 (5), 58-72.

Simpson, L. R. (2004). Finding effective intervention and personel preparation practices for students with autism spectrum disorders. Exceptional Children, 70 (2), 135-144.

Simpson, L. A., Sharon Q.; Kan H. \& Qing Qing T. (2016). Distance Learning: A Viable option for professional development for teachers of students with autism spectrum disorder in China. Journal of the International Association of Special Education. 1, 109-122, 14.

Smith, T. M. \& Ingersoll, R. M. (2004). What are the effects of induction and mentoring and beginning teacher turnover? American Educational Research Journal, 41 (3), 681-714.

Smith, S. J. \& Israel, M. (2010). E-mentoring: Enhancing special education teacher induction. Journal of Special Education Leadership, 23 (1), 30-40. 
Güleç Aslan, Y., \& Sola Özgüç, C. (2017). Öğretmenliğin ilk yıllarında otizm spektrum bozukluk tanılı öğrencilerle çalışan özel eğitim öğretmenlerine uygulanan mentorluk programının ikinci yllına bakış. Journal of Human Sciences, 14(4), 3548-3570. doi:10.14687/jhs.v14i4.4930

Sulek, R., Trembath, D., Paynter, J., Keen, D. \& Simpson, K. (2017). Inconsistent staffing and its impact on service delivery in ASD early-intervention. Research in Developmental Disabilities. 63, 18-27.

\section{Extended English Abstract}

\section{Introduction}

Teachers working with individuals diagnosed with ASD must have necessary professional qualifications. However, since programs from which many teachers working with individuals with ASD are graduated are not specific to ASD, these teachers start working without adequate knowledge and skills of ASD. Thus, they are more likely to have problems especially in the first years of career. Teachers unable to cope with these problems can face difficulties providing quality education to students (Ergenekon, 2005, 2009; Güleç-Aslan \& Sola-Özgüç, 2017; Scheuermann, Webber, Boutot \& Goodwin, 2003; Simpson, 2004; Sugita, 2016). Induction programs offered to these teachers in the first years of career foster their knowledge and skills. Thus, it promotes teachers' professional competence and facilitates their work adjustment. Induction programs can be executed as services aimed to help acquire knowledge and skills, mentoring, and consulting (Barnhill, Polloway \& Sumutka, 2011; Sulek, Trembath, Paynter, Keen \& Simpson, 2017; Smith \& Ingersoll, 2004).

Although literature research notes the importance of mentoring programs designed for teachers serving individuals diagnosed with ASD in the first years of career (e.g. Barnhill et al., 2011; Boyer \& Lee, 2001; Güleç-Aslan \& Sola-Özgüç, 2017), there is a limited volume of research on mentoring programs for these teachers (e.g. Boyer \& Lee, 2001; Güleç-Aslan \& Sola-Özgüç, 2017; Parker-Katz \& Hughes, 2008; Marder \& deBettencourt, 2012). However, investigating mentoring programs, especially through qualitative research, is of key importance for establishing quality mentoring programs (Güleç-Aslan \& Sola-Özgüç, 2017; Parker-Katz \& Hughes, 2008; Marder \& deBettencourt, 2012). The present study attempts to investigate the second year of an online mentoring program designed for teachers graduated from the Education of Mentally Disabled Program and working in the field of ASD in the first years of career.

\section{Method}

\section{Research Model} Participants

Qualitative case study was employed in this study.

The study participants include seven teachers graduated from the Education of Mentally Disabled Program of a state university and working in special education implementation centers (Autistic Children Education Center/ACEC attended by only students with autism) and dependent Autistic Children Education Centers (ACEC with special education classes for students with autism opened within the general education schools as part of inclusive education) (Female=6, Male=1). Five teachers have five years of experience in teaching profession and attended the first year of online mentoring program (Güleç-Aslan \& Sola-Özgüç, 2017). Two teachers are in the first years of career.

The process of conducting the online mentoring program

The online mentoring program was conducted as group mentoring and peer mentoring. It was maintained through e-mail group posts concerning the content determined every 15 days based on the needs of the participants.

Data Collection

The data was obtained through artifacts, opinion form, and researcher diary. 
Güleç Aslan, Y., \& Sola Özgüç, C. (2017). Öğretmenliğin ilk yıllarında otizm spektrum bozukluk tanılı öğrencilerle çalışan özel eğitim öğretmenlerine uygulanan mentorluk programının ikinci yllına bakış. Journal of Human Sciences, 14(4), 3548-3570. doi:10.14687/jhs.v14i4.4930

\section{Data Analysis}

The data was analyzed through descriptive analysis. The reliability and validity principles advised for qualitative research were ensured.

\section{Results}

The data analysis has yielded the following main themes: the content of the online mentoring program, the benefits of the online mentoring program, and the weaknesses and strengths of the online mentoring program. According to the analysis results, the program content consists of eight topics including orientation, student interaction, Alternative and Supportive Communication Systems (ASCS), expressive language, obsessive behaviors, course, seminar and congress, teaching methods and publication sharing. Another result is that the online mentoring program is helpful in fostering professional competencies, work adjustment, and job satisfaction. Three participants were satisfied with the online nature of the program. Three teachers reported the important benefits of the program as follows: determination of the topics discussed during the program based on their own needs and problems, sharing written and visual materials, providing both theoretical information and guidance on how to use this information. Additionally, two teachers reported the inclusion of personal issues (e.g. motivation, anxiety, etc). in addition to professional issues as the strength of the program. Only a few teachers $(\mathrm{N}=4)$ believed that face-toface interviews besides online presentations would promote the benefits of such programs.

\section{Discussion}

The results of the present study are consistent with literature research on mentoring. Mentoring programs planned and executed based on teachers' needs facilitate new teachers' work adjustment and promote their knowledge, skills, and job satisfaction (cf. Boyer \& Lee, 2001; Ergenekon, 2005, 2009; Güleç-Aslan \& Sola-Özgüç, 2017; Parker-Katz \& Hughes, 2008). This study seems to shed light on the process of planning and executing the online mentoring programs designed to help new teachers spend the first years of career successfully and beneficially.

Recommendations for practice: (a) related organizations and intuitions (ministries, universities, etc.) can develop mentoring programs, (b) pre-service special education teacher can be offered an increased opportunity for ASD-oriented courses and seminars in their undergraduate education.

Recommendations for future studies: (a) qualitative and quantitative research involving different participants can be carried out, (b) comparative research based on different mentoring models can be conducted. 